\title{
Binders full of LOLitics: \\ Political humour, internet memes, and play in the 2012 US Presidential Election (and beyond)
}

\author{
Geniesa Tay \\ University of Canterbury, New Zealand \\ geniesa.tay@gmail.com
}

\begin{abstract}
This paper examines the phenomenon of humorous Internet memes within the context of news and political culture, sometimes referred to as LOLitics. LOLitics are a category of digital texts created by ordinary individuals that, like most political humour, are usually responses to news events or gaffes committed by political figures. The analysis situates LOLitics as popular culture products that exist within the intersection between pleasure-driven 'play' and (arguably) genuine political discourse. LOLitics are prominent due to their spreadability and replicability, and the amount of texts being produced has visibly risen over the last election cycle. Internet memes have become one of the default ways to respond to particular situations online, and this certainly reflects the reaction towards news and political culture. The 2012 US Presidential election is applied as a case study in examining the significance of these Internet memes to everyday citizen discourse, and the relationships between ordinary citizens, the mainstream media, and politics. The results argue that humorous viral texts, both visual and verbal, reveal the potential power that ordinary people have in setting the agenda for newsmakers, and to communicate political criticism through popular culture.
\end{abstract}

Keywords: Internet memes, political humour, play, presidential elections, popular culture.

\section{Introduction}

Political satire and its significance is an increasingly popular field for academic enquiry. Countless recent studies have focused on the way television programmes such as The Daily Show and The Colbert Report have transformed political communication for a generation of young viewers, and their impact on political knowledge and participation are often subject to debate. Regardless of its influence on direct political action, comedy is often widely accepted 
as an inherently powerful form. For example, Heflin (2006: 31), writing about The Daily Show, considers laughter directed at political leaders as "dangerous to the status quo", suggesting that it can alter fundamental power relations.

Political humour on the Internet, however, is currently under-researched. The consistent development of new online platforms consequently enables more users to continuously produce unique forms of political humour, and should be a central focus in discussions regarding the popular citizen discourses surrounding politics. The potential power of Internet memes is often underestimated due to the transient and idiosyncratic nature of most texts. They do deserve more attention due to their popularity, which in many occasions extends beyond their online presence. This article therefore examines LOLitics - a combination of Internet memes and political humour, the essential factors involved in their production, and the changing nature of the digital landscape that enable their dissemination. The 2012 US Presidential election will be included here as a case study to explore and illustrate the potential of LOLitics for online users, and the consequences for broader news and political culture.

\subsection{Play an open texts}

Play theory is methodologically valuable in legitimising the frivolity and idiosyncrasies found in many humorous texts. It fits in appropriately with what many political satirists claim they are, that is, unofficial commentary that belongs outside the mainstream media system. An early conceptualisation of play theory was developed in 1938 by Dutch Historian Johan Huizinga (1949), claiming that play is essential to the development and generation of culture. His most applicable contribution is the notion of play as inherently instinctive, and driven purely by enjoyment (Huizinga 1949: 3).

That central idea is further appropriated by Jenkins (2011), whose theorisation of the core principles of play include passion, permission, participation, process, productivity, and pleasure. The principle of passion is already established by Huizinga, and to this Griffin (1994: 84) adds, "play is largely purposeless and gratuitous". Permission and participation are concepts related to open spaces that encourage play. Permission refers to environments that lower "the consequences of risks" and, consequently, become safe spaces for users to participate and experiment freely (Jenkins 2011). Within these environments, "play values process as much or more than product" (Jenkins 2011). Griffin (1994) stresses that while there are rules, such as aiming to match one's opponent in wit battles, moral standards are not paramount in play (Griffin 1994: 84-85). This openness can therefore lead to productivity, which includes individuals "trying out new structures", and ultimately, pleasure (Jenkins 2011). The texts in this case study exemplify the affirmation that fun is at the core of play, both as a motivator and a result.

As Fiske (1987: 236) summarises, "[p]lay is active pleasure: it pushes rules to the limits and explores the consequences of breaking them". This is definitely applicable to satire. In his analysis of The Colbert Report, Jones (2010: 199) points out the comedian's tendency to "destabilise" the rationality of right-wing pundits through exaggerated parody and contextual jokes. Colbert's audience are often more than happy to play along as "worshipful followers", viewing him as part of right-wing culture "through playful means" but still understanding the underlying mockery (Jones 2010: 229). In the case of Colbert, political criticism is therefore deployed through "serious play" (Jones 2010: 185). This feature can be applied to the user-generated pieces explored in this article. Alter (cited in Glasser 2000: 24) sees news stories as "a distinct and distinctively valuable opportunity for individuals to engage a very public world in a very private and personally satisfying way". 
Individuals often come up with their own interpretations of news stories, and Glasser (2000) encourages one to play with the news. To do so is to treat the news as an open text, reinterpret it in a language that one can make sense of, and experiment with its meanings. Instead of conforming to set narratives, individuals should make active decisions on what in the news matters the most to them (Glasser 2000: 27). The following exploration of Internet memes is evidence that Glasser's vision of a playful approach towards news and political media can benefit ordinary individuals.

\section{Meme mechanics}

Memes have become a mainstream culture buzzword, largely due to the ubiquitous presence of Internet memes and online popular culture. However, the term has been subject to frequent incorrect use - viral texts are often mistaken for memes. The differences between these two terms should be emphasised. Memes are units of information that are spread throughout society and culture. Like viral texts, they can be unpredictable in terms of their creation and lifespan (Danung \& Attaway 2008: 17). The core distinction between memes and viral units is the former's ability to replicate (Figure 1). Digital technology accelerates and furthers this process of replication, allowing texts online to be "inherently open to transformation" (Poster 2006: 245; emphasis in the original). Memes, including LOLitics, are continuously built "upon remix and appropriation", and their longevity depends on their ability to be adapted by users in ways that "explain the world around them" (Jenkins 2009).
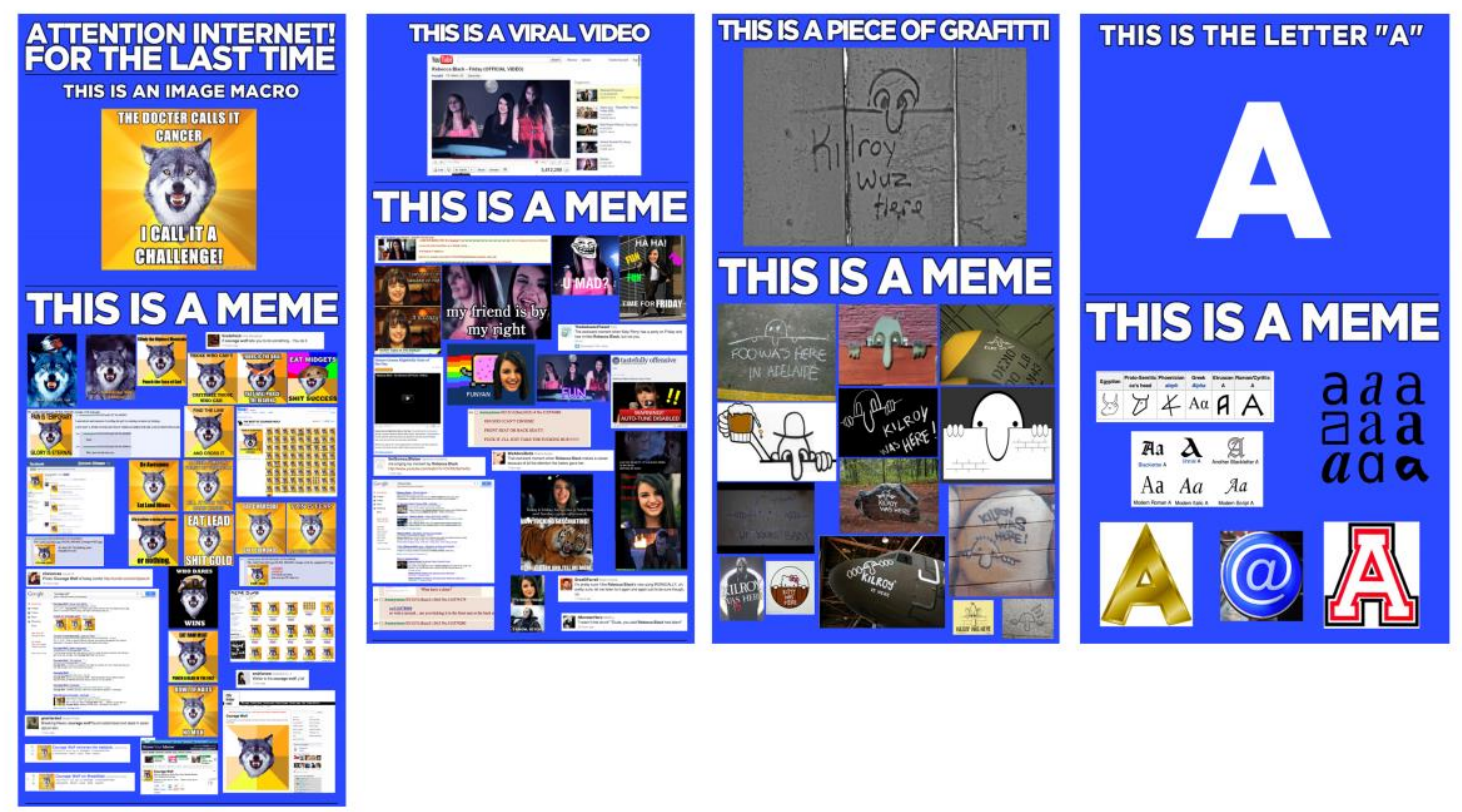

Figure 1. Viral texts are not memes.

While it can be used as shorthand to represent the political humour of Internet memes, the term LOLitics is relatively uncommon. It has however been utilized as a title or subtitle in some online spaces dedicated to political humour, including the now-defunct Pundit Kitchen, a section in the popular Cheezburger Network that publishes humorous texts focusing on news and politics. The Cheezburger Network is one of many online spaces that classify humorous takes on various genres by adding the acronym "LOL" as a prefix, as everyday language evolved to accommodate the inclusion of digital and mobile culture argot in offline 
vernacular. The term began in early USENET forums and its popular usage is largely inspired by the "LOLcats" meme, which is commonly considered as "the universal symbol of hilarity in the digital age" (Wired 2011: 28). The LOLcats are a quintessential example of a successful Internet meme, which simply employs a digital photograph of a cat accompanied by a funny, grammatically idiosyncratic caption, often framed by its writer as being from the feline's perspective. Like other Internet memes, LOLitics come in a multitude of formats, although this article focuses only on still images for various reasons. Firstly, they require less technical skill for creation, resulting in larger quantities being available. They are also consumable in short periods of time, which is especially beneficial in an age full of digital distractions. Finally, effective still images can communicate meanings within just a single frame, which can encourage further dissemination.

Most still image Internet memes, including LOLitics, can belong to either or both of the following categories: photomanipulated texts, and image macros. These two categories are essentially digital derivatives of pre-existing traditional media forms. Photomanipulated texts are approached in a manner similar to the use of green screens in filmmaking - the meanings of open texts are altered visually by cropping out a subject and placing them in an alternate setting. LOLitics that appear in this format are often a result of play with coincidental occurrences. For example, online users participated in the act of playful remix when unflattering candid photographs of John McCain during a debate surfaced online, morphing the former Presidential candidate into zombies, aliens, and other dehumanised characters (Figures 2 and 3). Photomanipulation takes an extra set of skills, though it is ultimately not difficult, especially with the availability of free software. It should be noted that like most Internet memes, the quality of production is varied- this however, this is also a prominent feature of play, which values process over product.
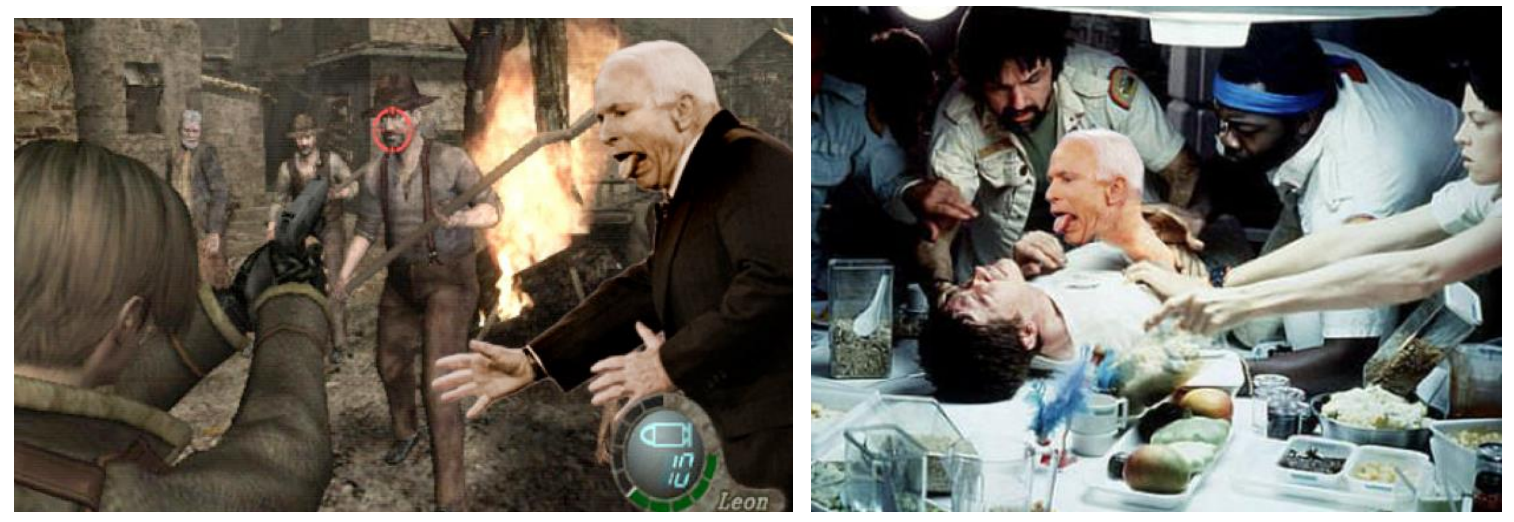

Figures 2 and 3. John McCain altered to look like a zombie in the Resident Evil 4 video game (left), and as a "Chestburster" in the popular science fiction horror movie, Alien (right).

From a technical standpoint, image macros are generally simpler to produce. Macros are used to run computer applications such as word processors in response to specific user commands. The term image macro bears little resemblance to the original definition of the word, though it is a widely accepted expression used to describe an image with a superimposed caption, usually for humorous effect (Rutkoff 2007). From this perspective, a macro can be seen as the automated processes that users go through to add captions to images in the accepted style. In this case, image macros commonly feature a bold, capitalised font (usually "Impact"), so the joke is at the centre of the frame and clearly visible, and the effect is often to an extent, emotional. There are countless variations in existence, but different image macros generally contain their own sets of rules especially in regards to joke-creation. LOLcats, for example, are always written in their trademark linguistic form, and image macros from the "Advice 
Animals" series generally include two sets of captions describing a before/after or cause/effect situation (Figure 4).

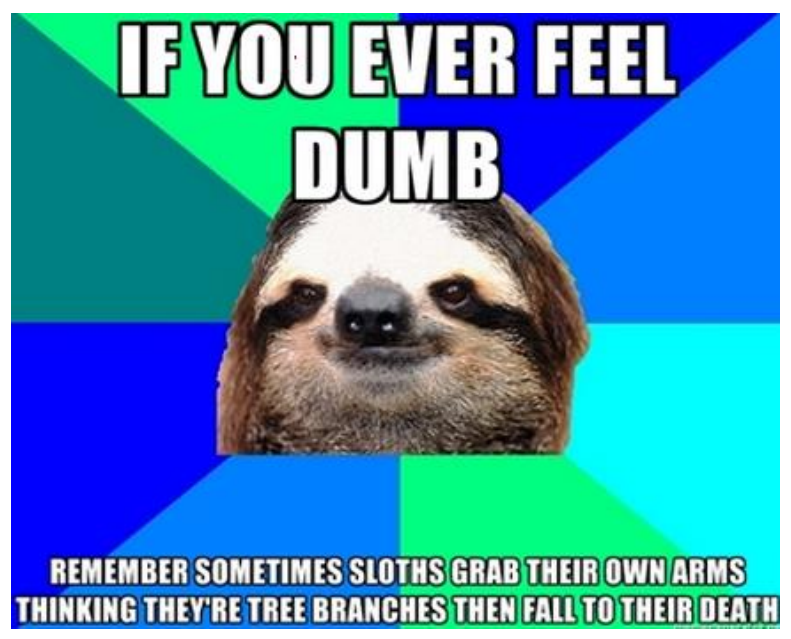

Figure 4. "Socially Lazy Sloth", an example of an image macro from the "Advice Animal" series.

Play is bound by rules. This is especially applicable to the image macro - users need to adhere to the humour style of the various texts they interact with in order to create a good joke. Like the analogue form of caption contests such as the ones run by The New Yorker, jokes can be either visual or verbal, but one usually encourages the other. The joy of creation and consumption therefore relies on the users' recognition of both the visual and the verbal joke. Lloyd \& Jewell's (2009: 66) study of a long-running caption contest in a Melbourne newspaper states that its appeal is in its encouragement of reader engagement due to its lack of a "pre-existing answer" - the entrant's own caption "solves the puzzle", and therefore, completes the joke. This resembles the act of playing with LOLitics. Users either attempt to complete a joke by adding funny captions to candid photographs of politicians, or in some cases, playing with what is already provided, thus furthering the spread of a meme.

\subsection{LOLitics and humour production}

Still-image LOLitics resemble editorial cartoons in several ways. LOLitics are often created in response to news or political culture, and in this are similar to editorial cartoons whose creators "are not reporters or editors [and] their material flows from the news" (Buell \& Maus 1988: 848). Both still-image LOLitics and editorial cartoons are able to comment behind the safety net of humour. Neither ordinary citizens nor editorial cartoonists hold any responsibilities to present factual information. Instead, both engage in the active reconstruction of meanings, and these two specific forms often do so within a single, or minimal amount of panels.

Producers of LOLitics and editorial cartoons are also involved in the act of "solving the puzzle" (see previous section). In order to do so, playing with various factors is required. Medhurst \& DeSousa's (1981) study on the art of persuasion in editorial cartoons is an applicable methodology to highlight how the humour in LOLitics is constructed. The framework, developed to examine political cartoons during campaign and election periods, is especially appropriate here. The topics drawn upon for humour production in their framework encapsulate features that should be recognised by the readers, creators, and perhaps even outside observers, especially throughout the recognisable context of election periods. The 
effectiveness of a text depends on the readers' familiarity with these factors. They include: political commonplaces, which are campaign occurrences, and news events that, according to Conners (2005: 481), are tied to "the political process itself". They may include any mention of policy, including "the economy", "foreign relations", and "campaigning" (Medhurst \& DeSousa 1981: 200). The second topic, literary/cultural allusions, is especially prominent in the commonly pop culture-heavy nature of LOLitics. Literary and cultural allusions refer to "any narrative or form, whether drawn from legend, folklore, literature, or the electronic media" (Medhurst \& DeSousa 1981: 201). To Conners (2005: 481), this includes any references to culturally specific texts in mediums such as television, films, books, and more. Situational themes, the third topic, are "idiosyncratic and transient situations which appear unexpectedly" throughout a political timeline (Medhurst \& DeSousa 1981: 200). These are "short-term situations" and are arguably of little political importance (Conners 2005: 481). Gaffes are a quintessential example of this.

The fourth topic deals with character traits (of a political figure). These can be subject to "physical or psychological exaggeration" (Conners 2005: 481). Either way, they draw "upon popular perception of the politician's personal character" (Medhurst \& DeSousa 1981: 202). LOLitics often target specific political figures, and therefore the expanded analysis here will incorporate Edwards's (2001) requirements for Presidential leadership. Edwards (2001: 2142) argues that editorial cartoonists use the following metaphorical representations to inform the reader of positive or negative qualities in a Presidential candidate. The criteria include:

1. Character: The display of ideals of a good leader in a specific candidate, including traits as "honesty, integrity, and consistency".

2. Viability: Presidential campaign cartoons that make judgments on a candidate's "potential for victory".

3. Competency: The inclusion of traits such as "intelligence, capability and political effectiveness" in a leader.

4. Charisma: Portrayals of Presidential candidates that allude to the "glamour or appeal", and "personality and likeability.

5. Independence: This was considered to be an issue of particular significance to the 2000 Presidential campaign; for example, Bush's connection to his father, and Gore's party affiliation with former President Clinton are considered to be possible "outside influences" to their ability to govern. A candidate that is able to be divorced from these factors allows them to be expressed as independent, and therefore a capable leader.

(Edwards 2001: 2142-2143)

\section{Journey to "The meme election"}

Election cycles are an especially inspiring time for humorous political commentary as much as they are for journalism. These periods are a political commonplace, and often contain multiple larger-scale, newsworthy political events, making them prime targets for scrutiny in both mainstream outlets and alternative spaces. While policies are important, the focus on political imagery pressures candidates into highlighting their personalities and campaign slogans. Street (2003: 96) considers politicians who appear "cool" in the eyes of ordinary citizens to be rare successes. They need to strike the difficult balance of being both "in charge and in touch", making political performances especially crucial. This indubitably makes gaffes seem all the more common. As explored later in this section in the case of Mitt Romney, LOLitics employ gaffes as opportunities for ordinary citizens to further communicate political criticism by treating him as an open text for play. 
The 2008 Presidential election was an especially momentous period in US history. The campaign trail emphasised not just the prospect of the country's first black President, but also the prominent involvement of digital media. Much has been discussed about the successful utilisation of social networking platforms such as Facebook, YouTube, and Twitter by the Obama campaign. The constant evolution of digital and mobile media, and the regular increase of users eventually led to these social media tools being seen as compulsory in marketing campaigns today. By the campaigning stages of the 2012 election, more digital platforms have emerged for user-generated content, and still images have become more prominent than ever. The popularity of photo-sharing platforms such as Instagram is evident in its incorporation into many marketing campaigns. More notably, Tumblr, a microblogging platform launched in 2007, became one of the most-used spaces for online users to express their opinions on the 2012 election campaign.

Tumblr stands out due to its function for "microblogging". Its interface resembles a conventional blogging platform, but unlike the long-form text often expected from bloggers, it encourages a comparatively minimal amount of content. This essentially results in the production of a short-form blog. Multimedia content, especially still images and animated $\mathrm{GIF}^{1}$ images, are especially popular. Tumblr's simple interface makes it easy to gauge a post's popularity based on how many users 'like' a post, and as an addition to conventional blogs, its "reblog" function allows a user to repost a copy of an existing entry on their own blog. This reposting function, combined with the sharp, quickly consumed quality of still images makes Tumblr the perfect platform for single-topic blogs, that is, spaces dedicated to singular jokes that can eventually develop into viral Internet memes.

Like many other social networks, Tumblr is utilised as a space for marketing and campaigning. Barack Obama's official campaign became a user in October 2011. The blog contains regular posts on policy issues, and high-quality photographs and graphics related to his Presidential campaign. This is reflective of the current news and political landscape, where officials strive to occupy and command the same spaces as ordinary citizens. Tumblr's staff certainly understands its prominence within political culture. In April 2012, they launched a blog dedicated to the 2012 Presidential election to cover conventions, debates, and memes. The blog has also covered Presidential debates by posting live GIF images, confirming not just the platform as a playful, pop culture-dominated space for political interaction, but also the use of still images as an instantaneous and easily consumable media form.

LOLitics were visible in many user-contributed platforms including Reddit and Twitter throughout 2008, but the 2012 Presidential election notably saw the mainstreaming of the Internet meme. What used to be 'insider jokes' in smaller web discussions and niche websites are being featured in the larger discussions about politics and pop culture. The news landscape itself, has evolved to adapt to these changes. Popular websites include Buzzfeed, which began as a space for popular culture commentary, evolved by including a politics-only section with its own separate editor, and later became a repository for their playful takes on politics, usually by using expressive GIF images from popular culture to explain complex political situations. ${ }^{2}$ Traditional mainstream news outlets, too, are gradually paying more attention to the political discourses that are significant in the online world.

There is an increasingly visible symbiotic relationship between mainstream outlets and those who "poach" information to produce LOLitics. The 2012 Presidential election shows that LOLitics can potentially shape the agenda for newsmakers. Journalist Ari Melber (2012) dubs 2012 as "the first Meme election": a time when "regular people [can] define [a] debate's big moments, competing with a role once reserved to the professional press". LOLitics spread throughout this election on a larger scale than before, and humorous commentary online has become an expectation. Know Your Meme's Brad Kim (cited in 
Jeffries 2012) deftly remarks, "[a]t the end of [each] debate, one of the quotes is going to become a meme. That's just how we expect things and how we interact with what's in the TV and what's in the news".

There are certainly prominent LOLitics that confirm Kim's expectations. For example, the 2012 Vice Presidential debate on October 16 between Vice President Joe Biden and Representative Paul Ryan led to a variety of responses focusing on the former's demeanour. Throughout the debate, Biden often visibly smirked whenever Ryan spoke. At times, the candidate was also laughing hysterically. This led to the creation of parody Twitter accounts chronicling his laughter, and a series of image macros focusing on his wildly expressive hand gestures. The image macro captions are generally relatively benign, and are not explicitly political, even if they may allude to both Biden and Ryan's viability as candidates. In fact, the humour appears more sophomoric than sardonic (Figures 5 and 6). This is evidence of play for play's sake.
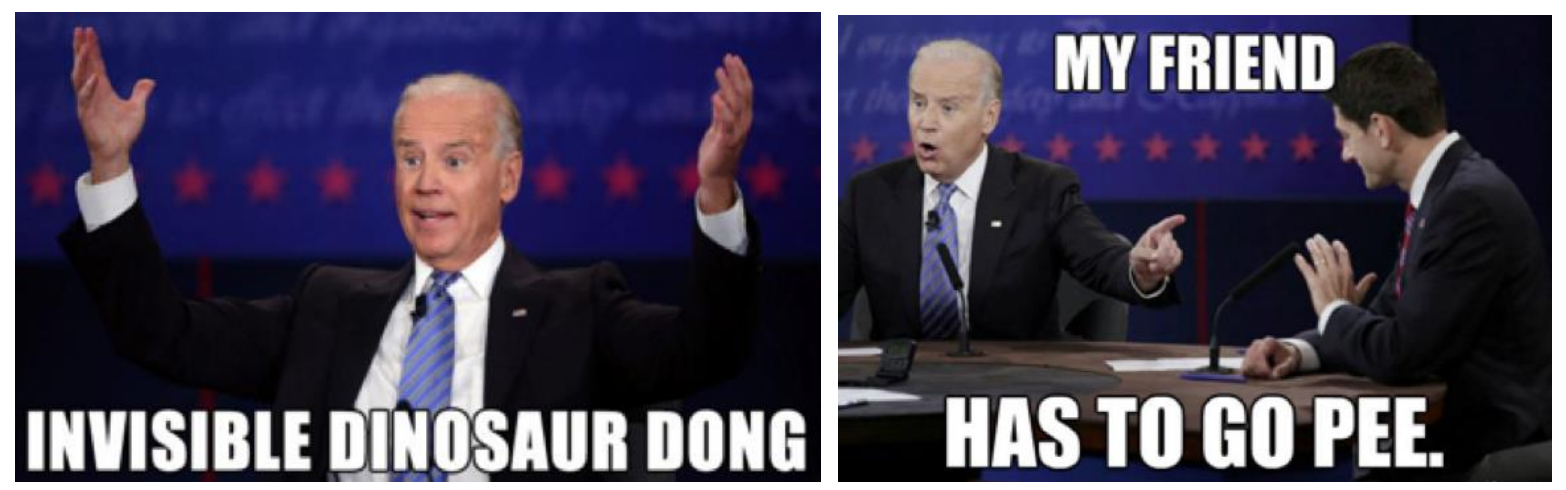

Figures 5 and 6. The Joe Biden captions are quite juvenile.

Early Presidential nominee Rick Perry too, was subject to this treatment. One of the early well-acknowledged single-topic blogs of the 2012 Presidential election cycle was created as a response to then-Presidential nominee Rick Perry's infamous Strong campaign video. The video advert was uploaded on YouTube by the Perry's campaign, and features Perry casually walking through a scenic outdoor setting as he verbally highlights his Christian values, and how they do not function in accordance with the 'Don't Ask Don't Tell' policy, and Barack Obama's 'War on Religion' (RPerry2012). Its approach towards GLBT and atheist communities however proved to be unpopular, and quite instantaneously garnered a phenomenal amount of 'dislikes' on YouTube with multiple parody videos eventually surfacing. The most popular response took place on a single topic Tumblr blog known as Rick Perry's Unpopular Opinions, appearing just two days after Strong was released. Its very straightforward format involves GIF versions of a segment of the video, and a superimposed quote assumed to be attributed to Perry proclaiming a popular culture reference that is widely considered as disagreeable, creating a light, albeit quantitatively successful commentary on the candidate's viability. Early examples include Perry proclaiming Jar Jar Binks as his favourite Star Wars character, and that cult television series Arrested Development deserved to be cancelled (Figures 7 and 8). The total of over 100 posts contained well-known and generally unpopular references to television programmes, contemporary fiction, pop music, celebrities, movies, and even technology-based jokes. 

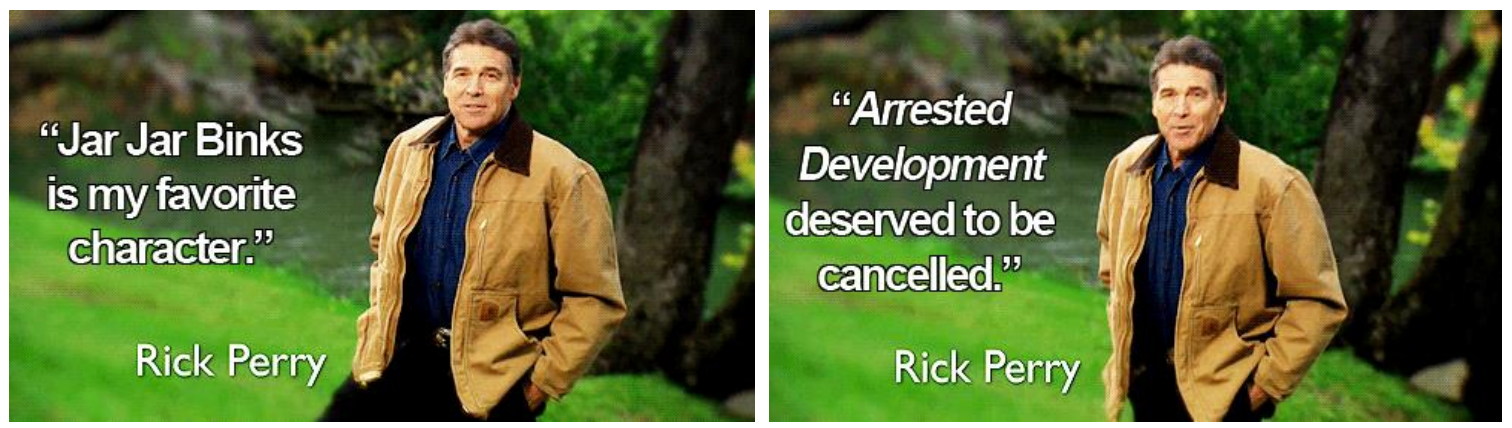

Figures 7 and 8 . Some very unpopular opinions.

This image macro is driven by cultural allusions. Rick Perry appears less as a political figure and more as a stand-in spokesperson for cultural incompetency. Within the world of Rick Perry's Unpopular Opinions, his likability as a character is only diminished because of his outlandish judgments on popular culture. The joy of humour creation therefore lies in the play and completion of a puzzle of mainstream popular culture. Interestingly, one of the major rules for user submissions imposed by the blog's creator, Kyle, is to not allow any references to Perry himself, or the Presidential race. This rule considerably limits the approach to Rick Perry to one that is not particularly political at all. The blog's coadministrator on the other hand, offers a slightly different outlook:

I'm hopeful that this blog at least somewhat contributed to the downfall of his presidential campaign and who knows, maybe in four years if and when he tries to come back, we'll be back too. There's really no telling with that man.

(Eric, cited in Rick Perry's Unpopular Opinions 2012)

While Rick Perry's Unpopular Opinions did not appear to be directly political, it certainly made an impact on the news agenda. The blog quickly received coverage from major mainstream news organisations, and it became so popular that, according to Tumblr statistics, Perry "easily became the most blogged candidate overnight" (Karp 2012). Kyle (cited in Newsweek 2012) originally started Unpopular Opinions because he found the Strong video to be offensive, but daring. He produced "a .gif [of Perry] calling himself a twat", and created a separate space for new images upon discovering that he "was enjoying putting words in [Perry's] mouth". The desire to have fun motivated Kyle, and in spite of the high volume of submissions received, he harboured no expectations to make a difference politically. The Rick Perry's Unpopular Opinions blog officially retired on January 31, although it was resurrected months later as a lesser-known blog known as Rick Perry Headlines. The new image macros are similar in tone, and more recent entries include posts on government policies and voting. The impact of the rebranded blog however waned, and is clearly dependent on the appeal of the former parody. The lack of longevity is a common characteristic of Internet memes, especially political ones. LOLitics, more than any other format of Internet meme, need to be contextualised by immediacy. While their impact is significant at a particular time, like news, gaffes, and the candidates themselves, they may eventually become less pervasive. The following two candidates however, inspired the two major memes during the 2012 election cycle, and more notably, represent the potential impact of play and LOLitics on mainstream politics. 


\subsection{Mitt Romney}

Presidential nominee Mitt Romney predictably garnered ample mainstream news coverage, especially after the Primaries. Though being the Republican Party's first Mormon Presidential nominee was a major talking point earlier in the campaign, the discourse eventually moved towards policy issues. Discussions of policy are reflected in Romney LOLitics, and online citizens also additionally directed plenty of attention towards his personality. As with the case of many other political figures, the playful rewriting of a character also takes place in other popular culture arenas, including Saturday Night Live, which over the past few years has garnered ample attention for its parody of Presidential campaigns. Saturday Night Live's Mitt Romney, played by Jason Sudeikis, is simultaneously perfidious, awkward, impassive, and ultimately, uncool- under stressful situations, he is often seen secretly getting drunk on milk. Under Edwards's (2001) classification, Romney is seen as unlikable, uncharismatic, and incompetent.

Image macros were consistently created and circulated throughout the Primaries. One of the earlier forms of Romney LOLitics is an image macro featuring a particularly awkwardlooking photograph of Romney and user-generated captions alluding to his wealth. The captions are generally light-hearted, and reminiscent of the popular hashtag "\#firstworldproblems", which is often used to punctuate intentionally sarcastic comments made by people who experience trivial inconveniences. Romney image macros were spread widely across online spaces driven by user submissions, including Reddit and Tumblr. A now-defunct single-topic website, Relatable Romney (2012a), and a Relatable Romney (2012b) Twitter account were created about five months after its first appearance. Cultural allusions and factual information, such as direct quotes rewritten in brasher tones, were commonly used to emphasise Romney's wealth (Figures 9 and 10). While the criticism towards Romney seems light-hearted, it does reflect a general consensus regarding the candidate's lack of charisma and inability to relate to the middle class; Buzzfeed dubbed it as "a meme for rich people to relate to" (Mezrahi 2012). 

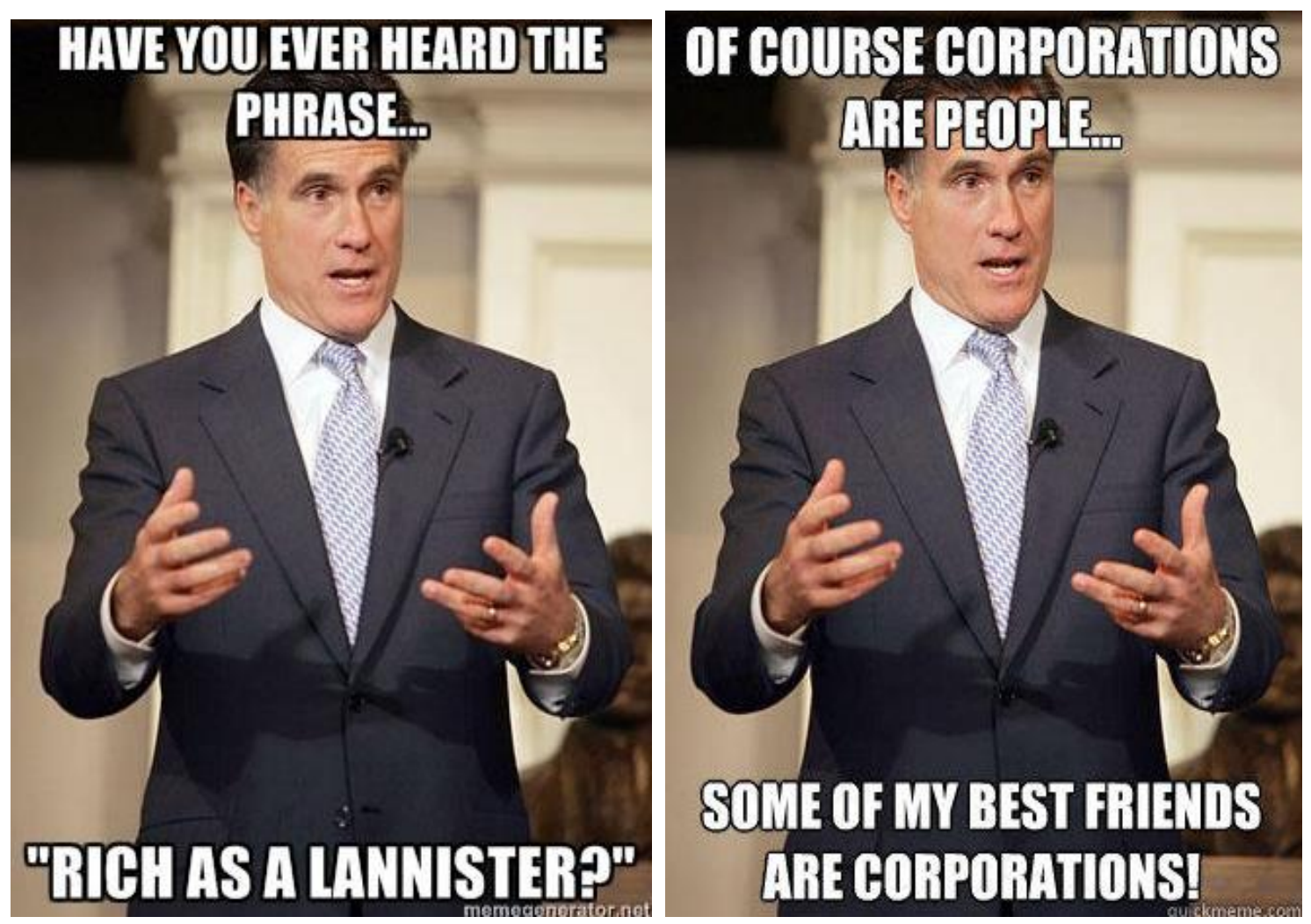

Figures 9 and 10. A cultural allusion (left), and a caption inspired by an actual Romney quote (right).

Single-topic blogs eventually became the dominant repositories for images created by users poking fun at Mitt Romney. His wealth also served as a punchline in the well-received Tumblr blog Lucille and Mitt. This single-topic blog contains photographs of Arrested Development matriarch, Lucille Bluth, accompanied by actual Mitt Romney quotes (Figure 11). The joke depends on the reader's knowledge of the cultural allusion: Lucille is an alcoholic spendthrift with little concerns for the working class, which extends to the ill treatment of her housekeeper, Lupe. The more popular posts retain the effect of juxtaposing Lucille's personality with specific Romney quotes that relate to immigration, the underclass, or workers' rights (Figure 12). Assuming Romney to be similar to a character in a beloved television programme could potentially cause the candidate to appear more likable, however, as O’Neal (2012) suggests,

many of Romney's quotes have an off-putting, patrician air that makes him seem like he's disdainfully removed from the filthy common man. However, put those same quotes over a photo of Arrested Development's Lucille Bluth, and they sound disdainfully removed from the filthy common man in a hilarious way.

Solving the Lucille and Mitt puzzle allows users to match the unlikable characteristics of the two together. It is playful, results in humorous take on a potentially dour subject, and overall highlights the lack of integrity in Romney's character. 

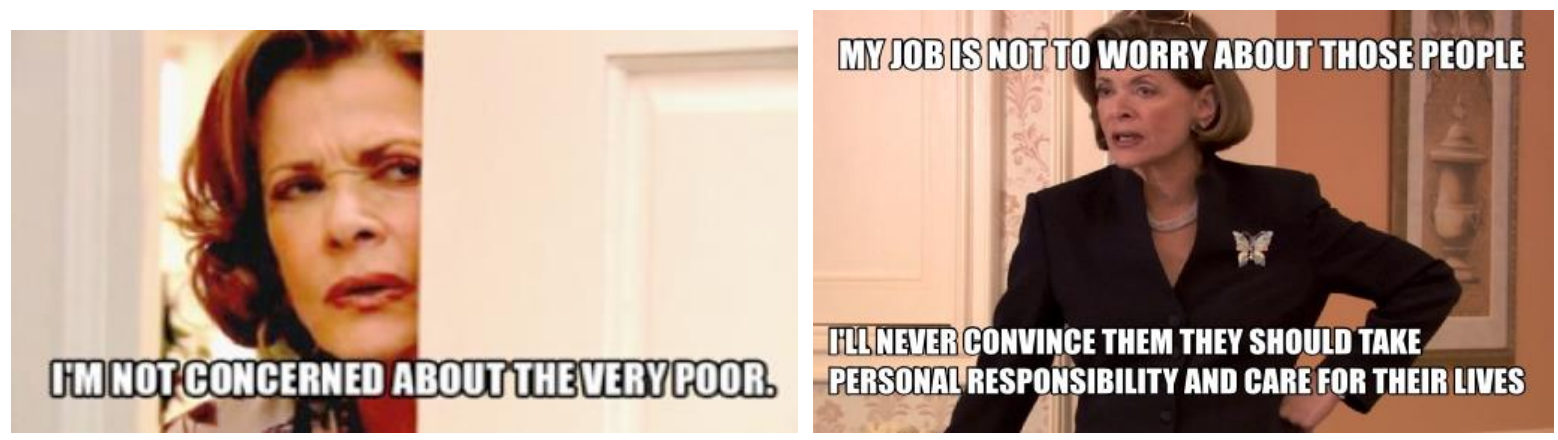

Figures 11 and 12. Lucille Bluth as Mitt Romney, or vice versa. Figure 12 (right) directly combines references to the treatment of the underclass by both characters.

The interpretations of Mitt Romney's character, charisma, and competency in single-topic blogs such as Romnoid: The Republican Android and RomCom 2012 mirror the Saturday Night Live persona. Both Tumblr blogs have been featured on mainstream popular culture websites. The former contains quotes by "Star Trek's Commander Data juxtaposed against photographs of Mitt Romney designed to create what humans call 'laughter"' (Romnoid 2012). The producers' intention to create jokes is clear, and Data, who as an android in the television series is unable to feel emotions or human empathy, is a well-matched cultural allusion. The juxtaposition of the cultural allusion and a recognised negative perception of Romney's personality as "robotic" directly target the candidate's awkward, unsympathetic personality (Figures 13 and 14). Rather than referring to Data's logical prowess, the meme focuses on his alienation. It is potentially dehumanising, though like Lucille and Mitt and Saturday Night Live, it may be more likely to amuse. Although his impassiveness could potentially be used to some effect in RomCom2012, the single-topic blog's seemingly benign posts hint at the candidate's competency and viability. The short-lived RomCom 2012 features photomanipulated pieces - Romney's face is cropped to replace the male lead in romantic comedy posters, and a parody film tagline is included in plain text underneath the image. Romney is assigned to a stock character often classified as "a noble/reluctant/ambitious billionaire" attempting to gain the love of his nation, but not without encountering mishaps in between. Romantic comedy plots are offered as a familiar cultural allusion for readers to play with, revealed largely in the tagline. Here, there is freedom to comment on Romney's competency and viability. A Knocked Up parody, for example, is used to negatively frame Romney's controversial issue regarding "legitimate rape", and a Failure to Launch spoof hints at his inability to run a successful campaign (Figures 15 and 16). RomCom2012 shows that through genre play, online users are able to allude to more serious political issues through a recognisable, light-hearted format. 

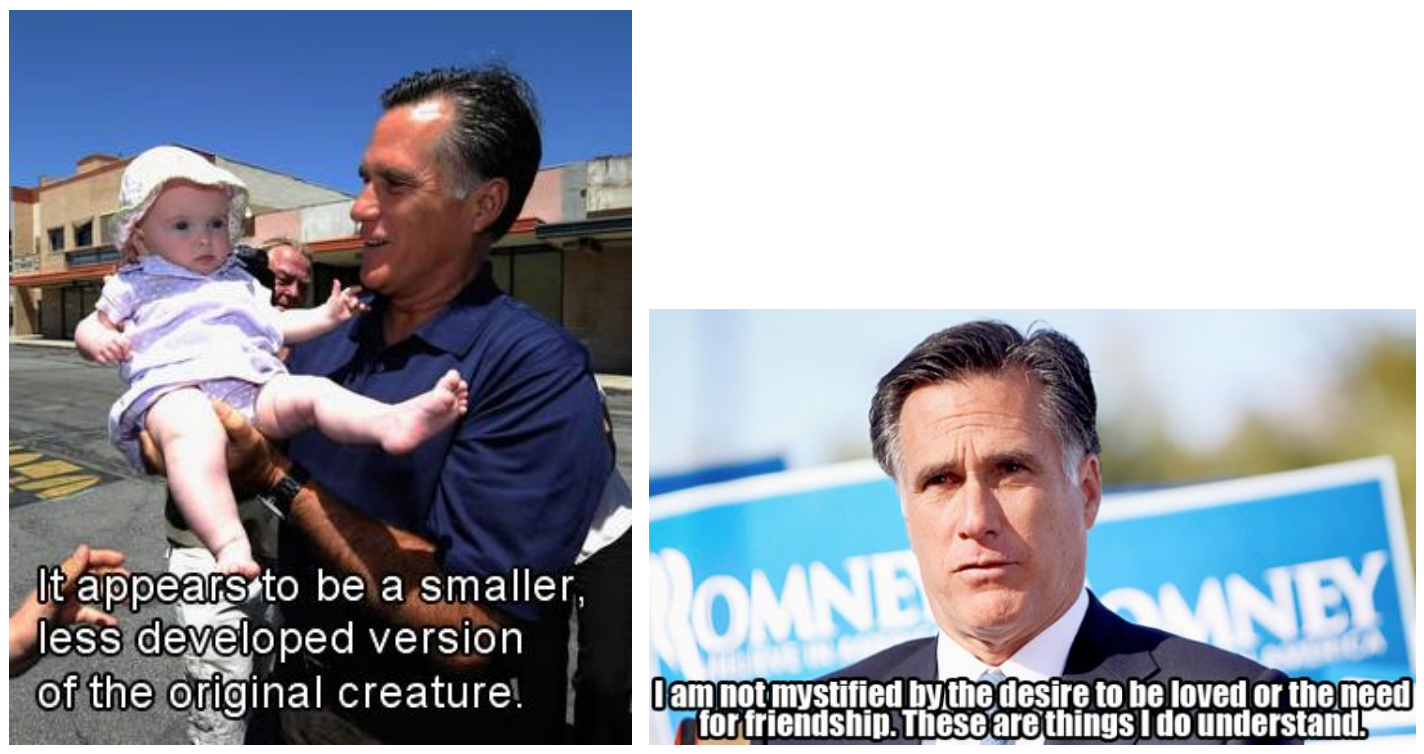

Figures 13 and 14. Romnoid has difficulty registering human emotions.
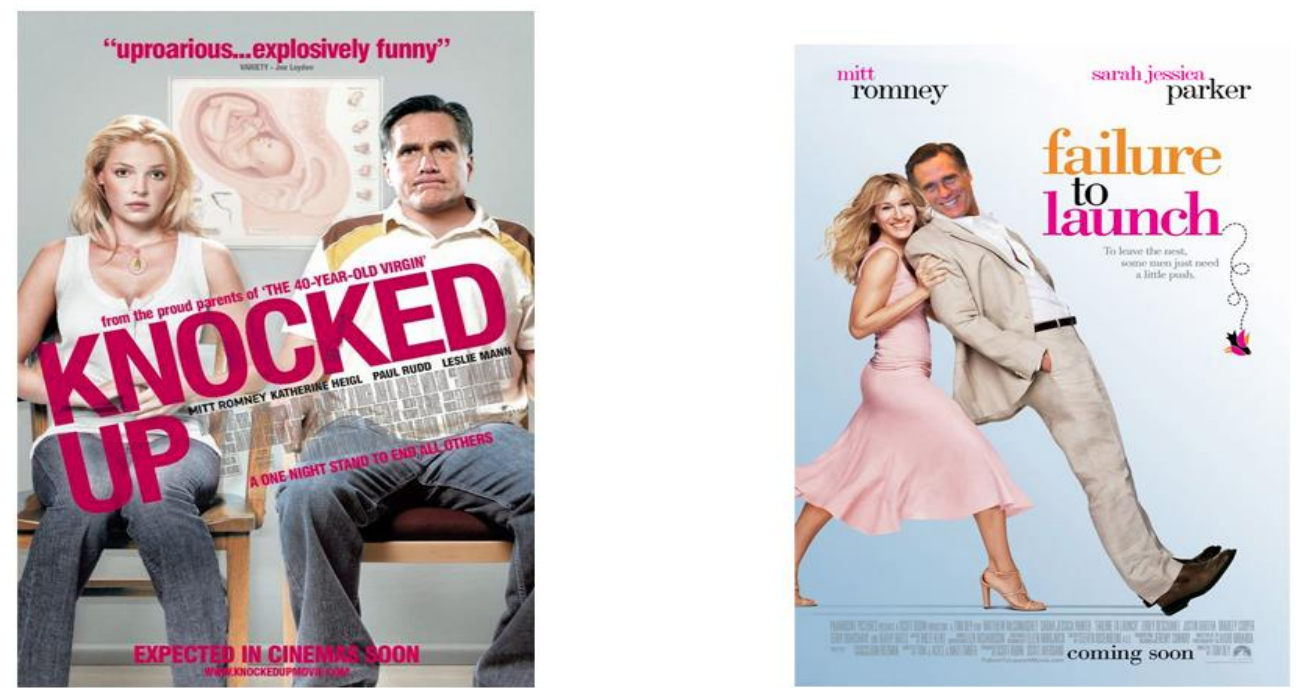

A billionaire and his friend from Missouri get a hard life lesson when they meet A reluctant billionaire seems to have it all, but when he runs for office, all the the rarest of women - a legitimate rape expecting mother. financial backing in the world still can't get his campaign off the ground.

Figures 15 and 16. Parodies of Knocked Up (left) and Failure to Launch (right).

In addition to gaining coverage on popular culture sites, the following prominent Mitt Romney-related memes managed to steer the agenda of the mainstream press towards online citizen discourse. They became not only popular online, but have expanded beyond the sphere of the inside joke, and affected offline political discourses. Both of these memes capitalised on situational themes that occurred within a political commonplace. Garfield \& Gladstone (2011) explain that "all of campaigning is theatre", and gaffes essentially "strip away that veneer" to uncover the real person behind the slickly produced candidate. As candid moments, gaffes provide evidence that can harm a candidate's credibility. Treating gaffes as open texts, and remixing them with the appropriate cultural allusions can further undermine the political figure's potential as a candidate.

The "Fire Big Bird" meme occurred as a reaction towards a statement Romney made during the first 2012 Presidential Debate on October 3, 2012. In response to a question about 
the country's deficit problem posed by the moderator, PBS journalist Jim Lehrer, Romney inadvertently included Big Bird in one of his answers:

I'm sorry, Jim, I'm going to stop the subsidy to PBS. I'm going to stop other things. I like PBS, I love Big Bird. Actually like you, too. But I'm not going to - I'm not going to keep on spending money on things to borrow money from China to pay for. That's number one.

(CNN Political Unit 2012)

Online users instantly expressed their disagreement. Twitter data revealed that Big Bird was mentioned in posts over 17,000 times per minute, and it became an increasingly popular search term on Google (Bingham 2012). Hashtags such as "\#savebigbird" trended worldwide, and parody Twitter accounts of victimised, unemployed Big Birds were created. Romney may have explicitly stated his "love" for Big Bird, but online users interpreted this differently and rewrote the discourse as the candidate's "War on Big Bird". The candidate's attempt to relate to the nation by referencing a beloved children's television character backfired, and became a significant factor in undermining his own campaign.

Various image macros were circulated on Reddit, Tumblr and Facebook. Most supported Big Bird's unfortunate situation and disdain towards Romney with emotional messages (Figures 17 and 18). Others compared Romney axing Big Bird to Barack Obama killing Bin Laden (Figure 19). This meme received coverage on every major US news outlet, and mainstream popular culture reacted accordingly. Big Bird made a guest appearance on Saturday Night Live's news segment, Weekend Update, but oddly opted not to make any political statements. More notably, the Obama campaign took advantage of the gaffe and the buzz it generated online. A satirical Obama for America (2012) television commercial was released a week following the incident. The parody attack advertisement only contained images of convicted financiers such as Bernie Madoff, Romney and Big Bird, and an ominous-sounding voiceover suggests, "Mitt Romney knows it's not Wall Street you have to worry about- it's Sesame Street". A statement by the Sesame Workshop later confirmed that the accusations against Romney were "misleading", because they actually receive "very, very little funding from $P B S$ " and will remain in existence regardless of the election outcome (Parker 2012). Still, this fact became buried in the major discourse of Romney as a villain. Through the playful rewriting of Mitt Romney as the cause of Big Bird's unemployment, users online also framed him as unlikable, and strongly hinted at his declining viability as a winner.
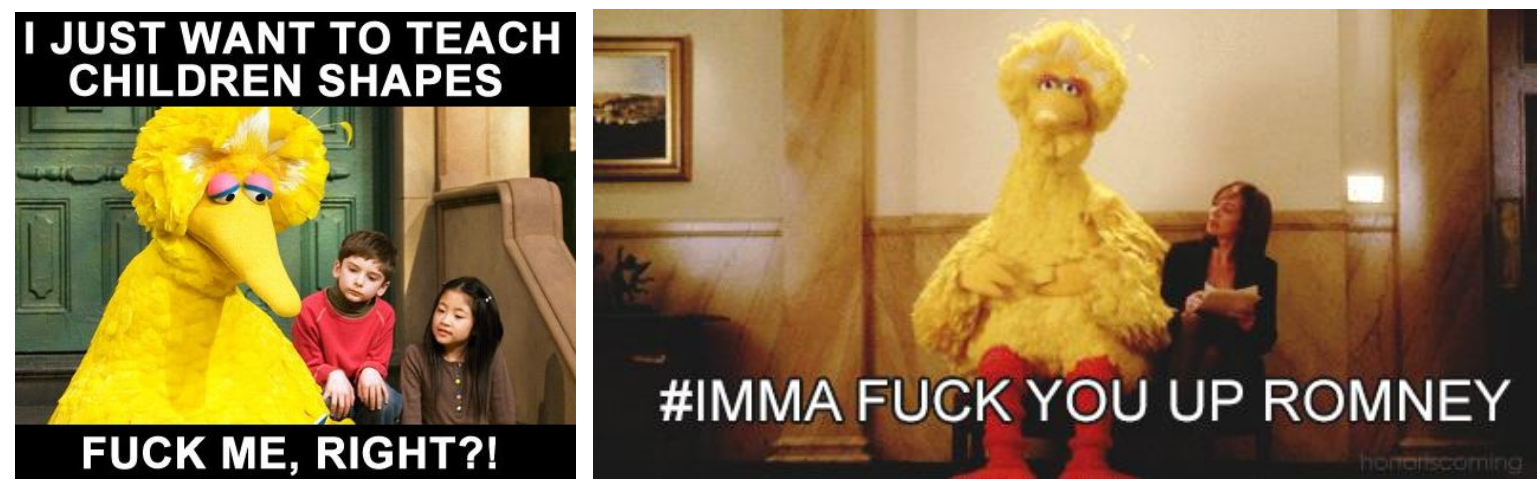

Figures 17 and 18. Big Bird's supporters expressed grief and anger. 


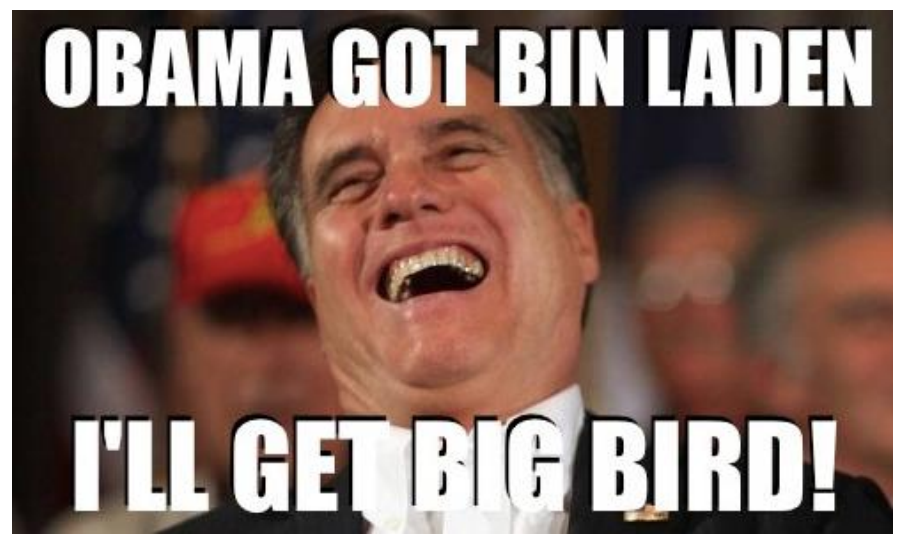

Figure 19. It is like killing bin Laden.

If the Big Bird meme managed to hurt Mitt Romney's campaign, then Binders Full of Women solidified the negative perception online users already directed towards the candidate. This took place during the second Presidential debate on October 16, 2012. An audience member directed a question at Romney regarding pay equity, asking him how he would "rectify the inequalities in the workplace" (Cardona 2012). The candidate then referred to his experience as the Governor of Massachusetts, where "I had the chance to pull together a Cabinet, and all the applicants seemed to be men... I went to a number of women's groups and said, 'Can you help us find folks?' and they brought us whole binders full of women" (Romney, cited in Cardona 2012). While the comment can seem innocent enough, Internet users felt otherwise, and immediately responded to the gaffe. The "binders" comment instantly went viral on Twitter, where parody accounts such as @womaninabinder and @ RomneysBinders were created. A 'Binders full of Women' page appeared on Facebook and quickly gained over 300,000 'likes', and Amazon's binder pages were inundated by humorous reviews (Figure 20, Grossman 2012).

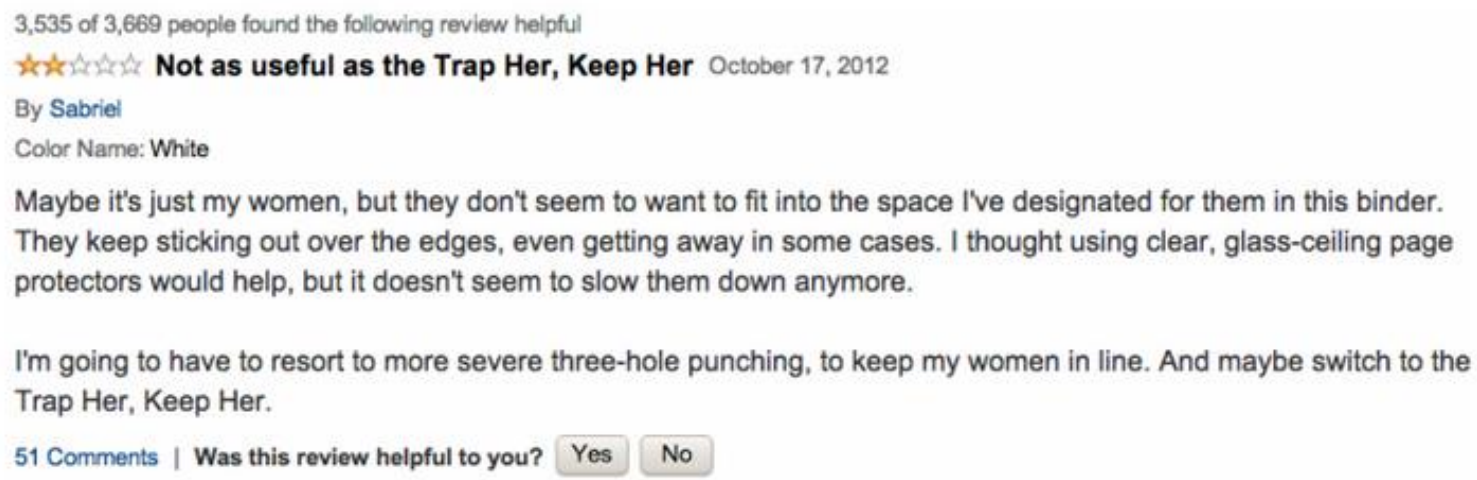

Figure 20. An Amazon binder review.

A Binders Full of Women single-topic Tumblr blog was also created, and published over 400 submissions within its 38 days of activity. Binders Full of Women is successful as a base situational theme to play with due to its simplicity and social demographic. The involvement of women and a benign inanimate object serve as eligible open texts, which users have played with in their photomanipulation and image macros. The submissions on the Tumblr blog are eclectic, and ranged from visual puns on the phrase (Figure 21), to the use of cultural allusions such as remixes with other Internet memes (Figure 22), and the use of popular culture figures to respond to the quote (Figure 23). Most of the meme's submissions seem to focus solely on the humour value- though this is already context dependent- of the phrase. 
Hess (2012) suggests that in the "narrow context of the 2012 election [the phrase] is worth mocking for one reason: Mitt Romney said it", and the meme loses its power when "it makes no sense as political critique".
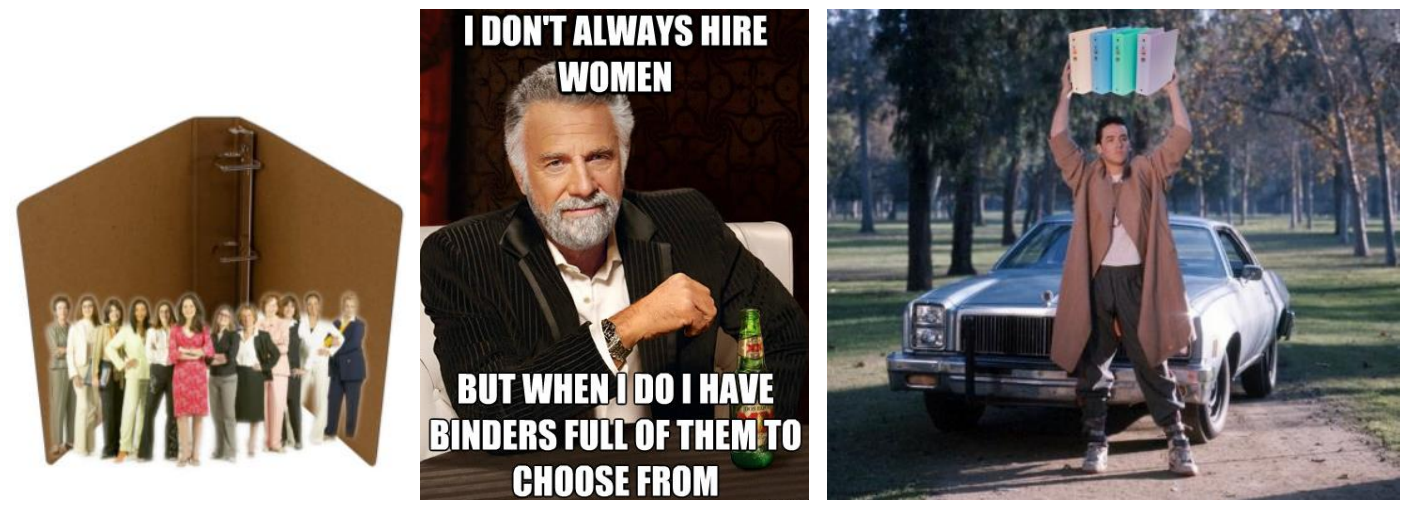

Figures 21, 22, and 23. Binders full of women.

While there is certainly truth in Hess's argument, Binders Full of Women did successfully highlight Romney's unpopularity with women (Cardona 2012). Some genuinely angry and politicised examples can present themselves in the midst of the presumably purely playful submissions. For instance, one of the most popular submissions is a parody of an Uncle Sam recruitment poster featuring a drawing of former Saturday Night Live cast member Amy Poehler on a recent Weekend Update segment (Figure 24). The character looks furious, and the bold text reads, "DON'T PUT ME IN A BINDER". The image, unlike many Internet memes, is skilfully crafted, and received over 1,400 notes. Online users here have clearly adopted Amy Poehler's powerful voice as a feminist, a recognisable cultural allusion, to express their anger towards Romney. The cultural allusion is additionally fitting, for the original source is of Poehler passionately criticising the lack of women in a congressional committee on birth control, but retaining her position as a comedian. This mix of the purely playful and "serious play" is also visible in the meme's offline presence - the situational theme's proximity to Halloween also allowed the meme to expand into costumes offline (Figure 25). On the directly political scale, to protest the remark women dressed as binders outside Ohio's Republican Party headquarters (Bobic 2012, Figure 26). The Binders Tumblr page creator Veronica De Souza (cited in Hess 2012) confesses, "I really didn't make this for any political reason. I just thought it was funny". This initial motivation makes the meme a result of the act of play. What is up for further questioning, however, is if LOLitics can therefore genuinely inspire offline political action, pursued through the example of Texts with Hillary. 


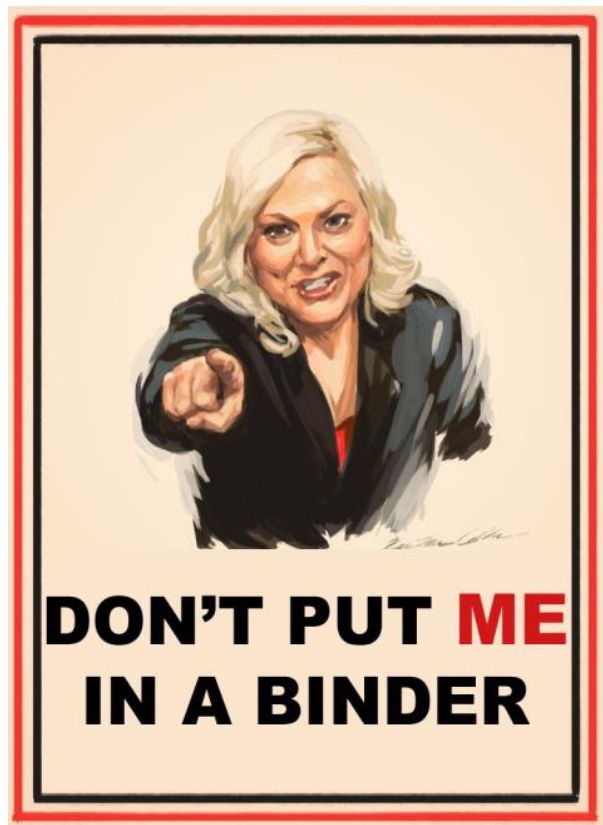

Figure 24. Parks and Recreation's Leslie Knope responds.
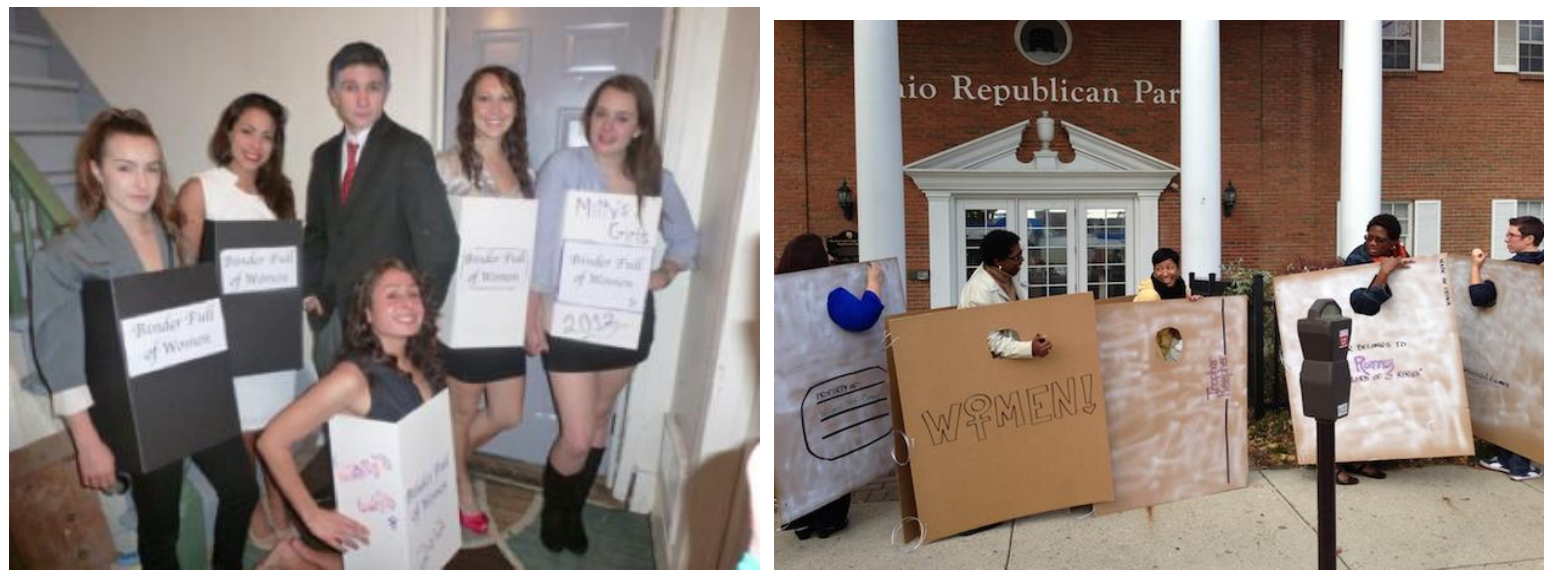

Figure 25 and 26. Halloween binder costumes (left), and an anti-GOP protest (right).

\subsection{Beyond the election meme: Texts with Hillary}

The 2012 election cycle online commentary featured starkly contrasting approaches by feminists towards Mitt Romney and Hillary Clinton. On April 4, 2012, a 2-panel image containing separate photographs of President Barack Obama and then-Secretary of State Hillary Clinton, both texting, were posted on a Tumblr blog. It imagines an exchange between the two, with Obama casually asking Clinton, "whatchu doing?" to which she responds, "Running the world" (Figure 27). There is a symmetrical juxtaposition between its verbal and visual content. Obama is relaxed, positioned as lying down while simultaneously reading and texting. Clinton has a solemn expression, is wearing sunglasses, and appears to be reading messages on her PDA while working on a large stack of reading material. The Tumblr post received over 9,000 notes within the first two days, and at the time of writing, it has clocked over 13,800 notes. 


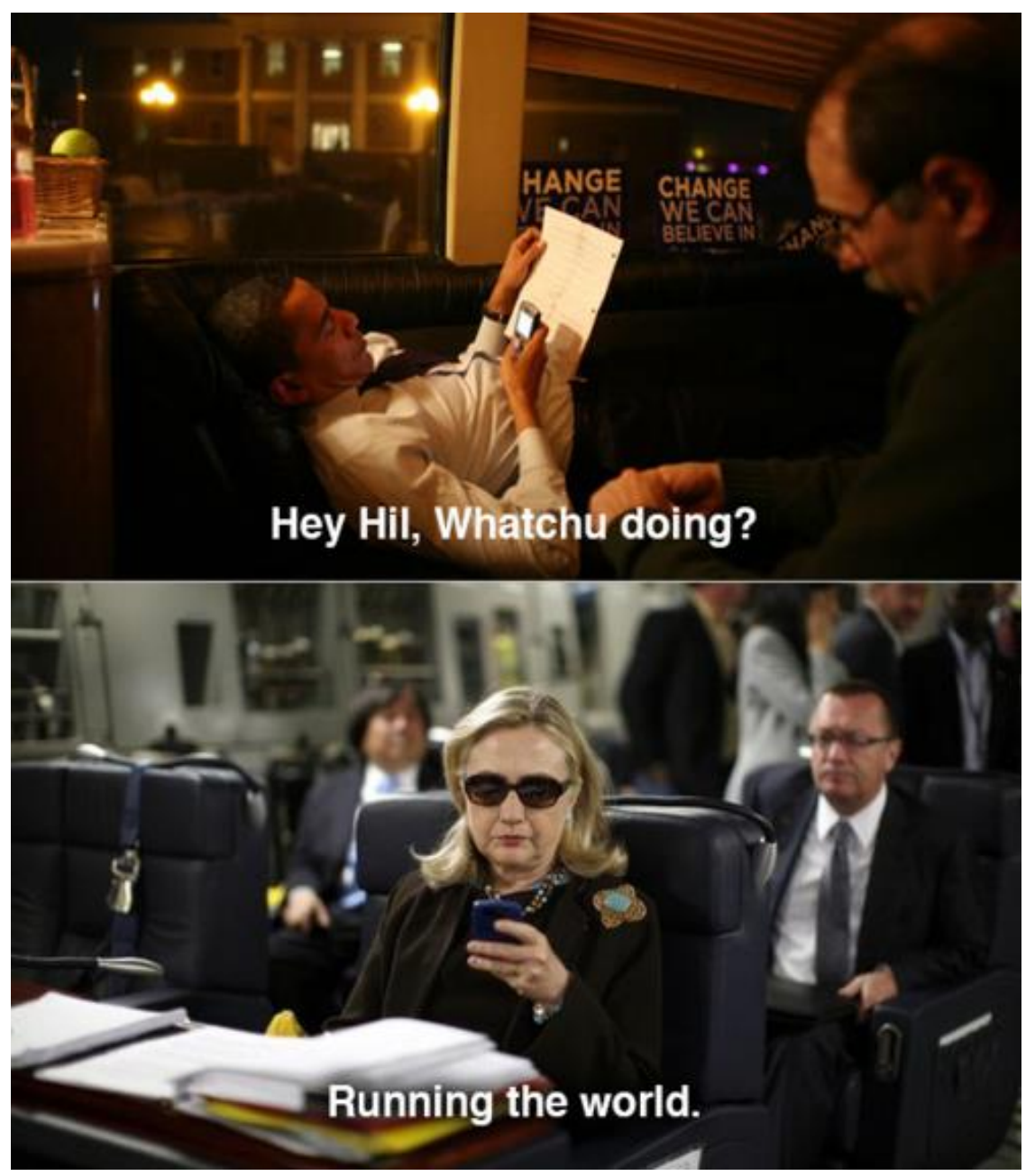

Figure 27. The original Text with Hillary.

More mash-ups were quickly published on the viral single-topic Tumblr blog, Texts with Hillary. In the image in the first post, rather than her original photograph alone, Clinton naturally commands authority. This instantly became the unwritten rule for a successful Texts with Hillary meme, and the tone of the other submissions adhered to this format. Hillary Clinton has been rewritten as, to put it colloquially, a badass. In the realm of LOLitics, Clinton receives distracting texts from colleagues, political rivals, journalists, television personalities, pop stars, and other pop culture figures. She shuts down her rivals, such as Sarah Palin, with one-liners (Figure 28). Her work ethic and serious nature is often reinforced when colleagues are involved (Figure 29). She is not prone to flattery from celebrities (Figure 30), but will accept brunch with award-winning and highly venerable thespian, Meryl Streep (Figure 31). Clinton becomes a pinnacle of class, respectability, and a representation of female empowerment. This is particularly well illustrated in the mock conversation with liberal political commentator Rachel Maddow, in which Clinton confirms, girls do run the world (Figure 32). 

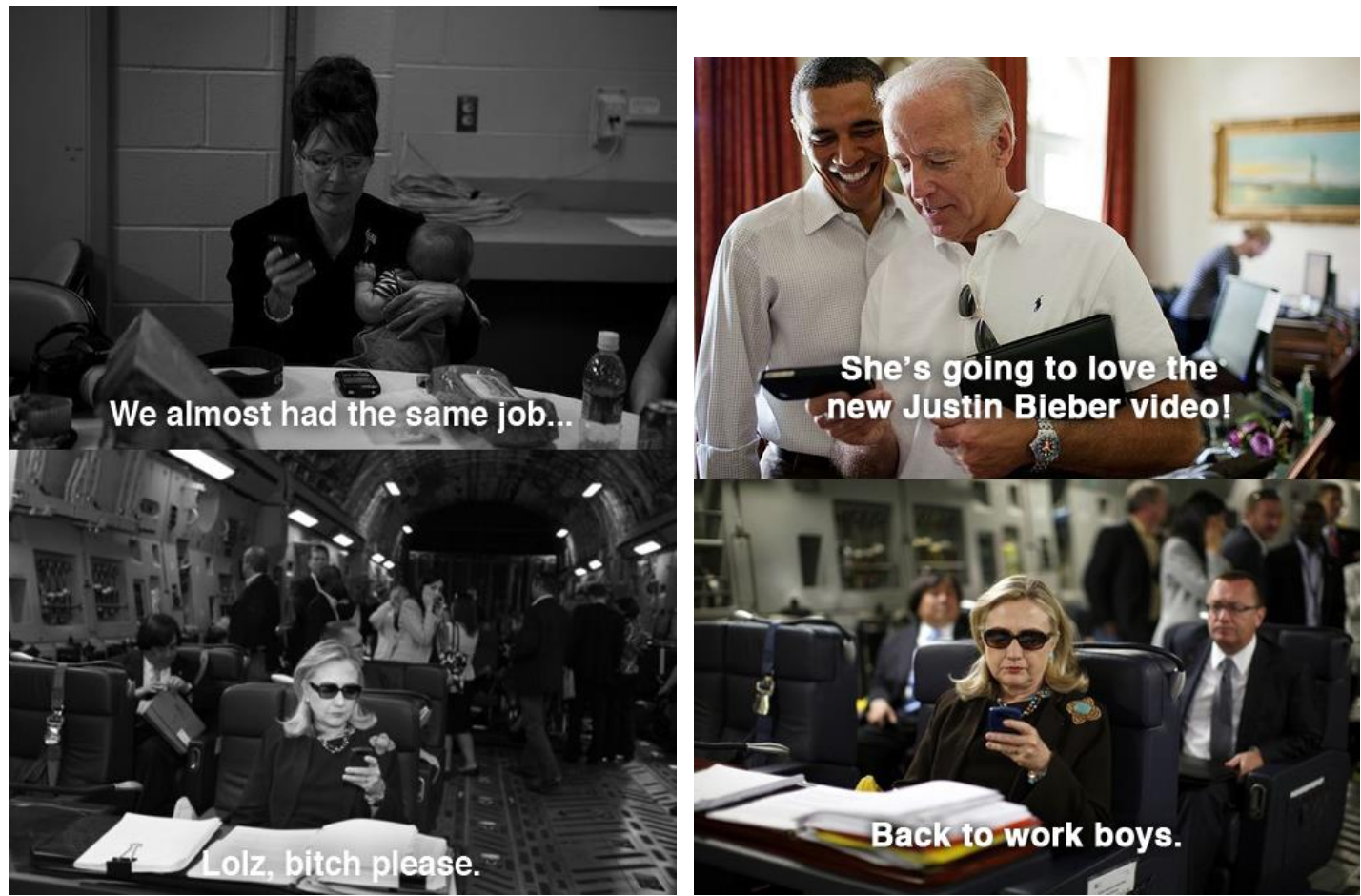

Figures 28 and 29. Clinton responds to Sarah Palin (left) and Joe Biden (right).
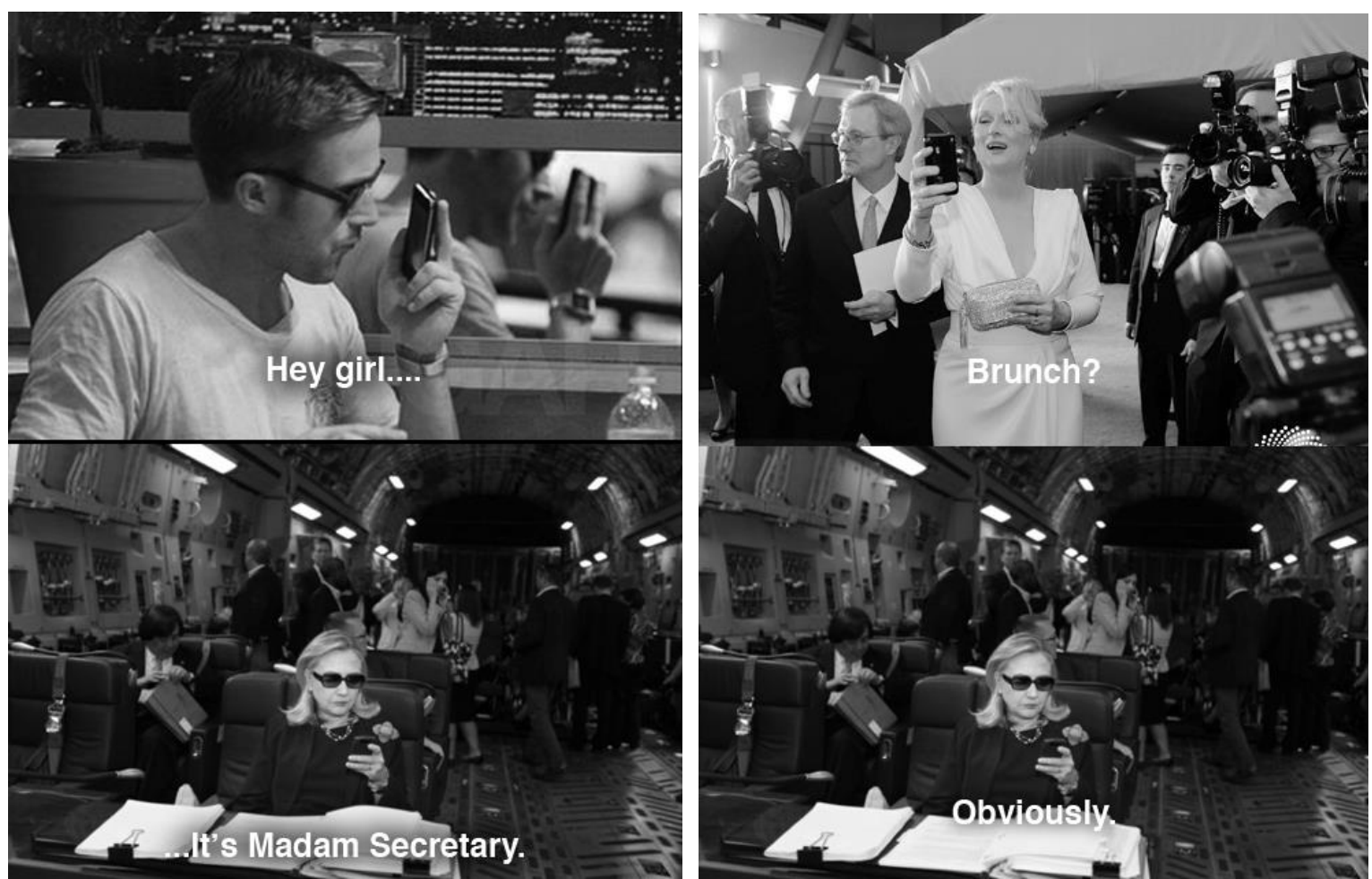

Figures 30 and 31. No love directed at Ryan Gosling, but Meryl Streep gets brunch. 


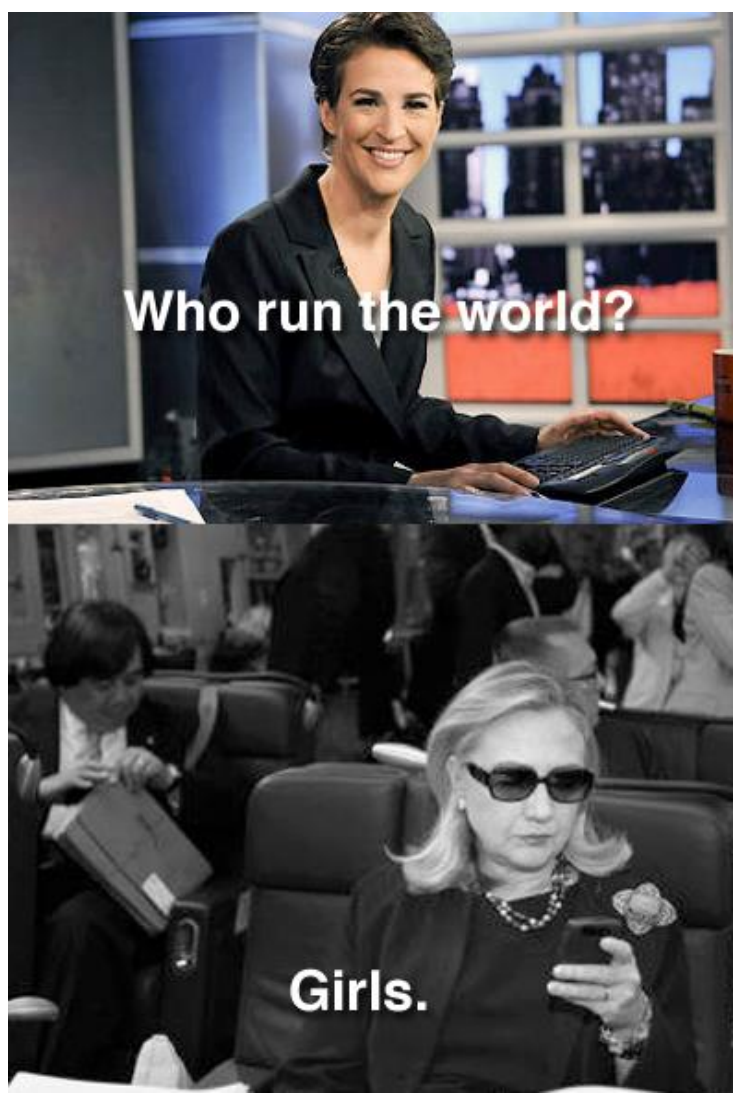

Figure 32. Girls who run the world.

Beyond some appearances throughout the Obama campaign trail, Hillary Clinton's involvement in the 2012 Presidential election was minimal. LOLitics targeted at GOP candidates were heavily circulated throughout this period, and the appearance of a Hillary Clinton meme, because of its detachment from a political commonplace or situational theme, is an anomaly. The two original pictures of Clinton were taken from different angles by Reuters photographer Kevin Lamarque, and as part of a photo essay by Diana Walker for TIME before her departure on a military C-17 plane bound from Malta to Tripoli on October 18, 2011 (Basler 2011; Sun \& Moakley 2012). There is no direct connection between the original photographs and any news stories related to Clinton. The viral text originated when Stacy Lambe came across the Reuters photograph, and over drinks with his friend Adam Smith, "tried to figure [it] out" (Kitroeff 2012). The first step to solving this puzzle was asking what "could be important enough to distract Hillary from the entourage surrounding her on that Libya-bound plane?" and the answer was that "she has a text" (Kitroeff 2012). The two friends worked in Public Relations, and had inklings that the post could go viral. The overwhelmingly enthusiastic reception, however, was unexpected.

The positive nature of the meme too, makes it a unique case study. With few exceptions, LOLitics often make fun of their targets, bringing them to the level of ordinary individuals or lower, even if the viability of a candidate remains unaffected. A photograph of Barack Obama wielding a toy Lightsaber for instance prompted users to playfully frame him as a protagonist in many Star Wars-related scenes, among other cultural allusions (Figure 33). Participants lightly poked fun at the President's well-known nerdy reputationpotentially disrupting his "cool" factor, without further commentary on his politics. When an unlikable candidate becomes a target, LOLitics can become tonally critical. Texts with Hillary, however, openly bestows a confident persona upon Hillary Clinton that is previously uncommon in her media or pop culture portrayals. Through this meme, online users rewrote 
the discourses surrounding Clinton's character - she is now witty, competent, and independent. Journalist Megan Garber (2012) calls it "a pitch-perfect fusion of irony and respect", and the creators confess that they mean to be nothing but complimentary towards Clinton. This meme is not explicitly political, nor is it intended to be. Lambe (cited in Casey 2012) comments,

Texts from Hillary came about at the right time that really spoke to what was the undercurrent of the current mood in Washington, as well as apparently the nation. We created something that was definitely very genuine and real. I think it was funny. It was simple, and it kept it politics free, which I know sounds bizarre because it's labelled as one of the best political memes of this year. But our idea was to never take a stance on a certain issue, it was capturing the idea or persona of someone we've all come to know and then letting people have an outlet for that.

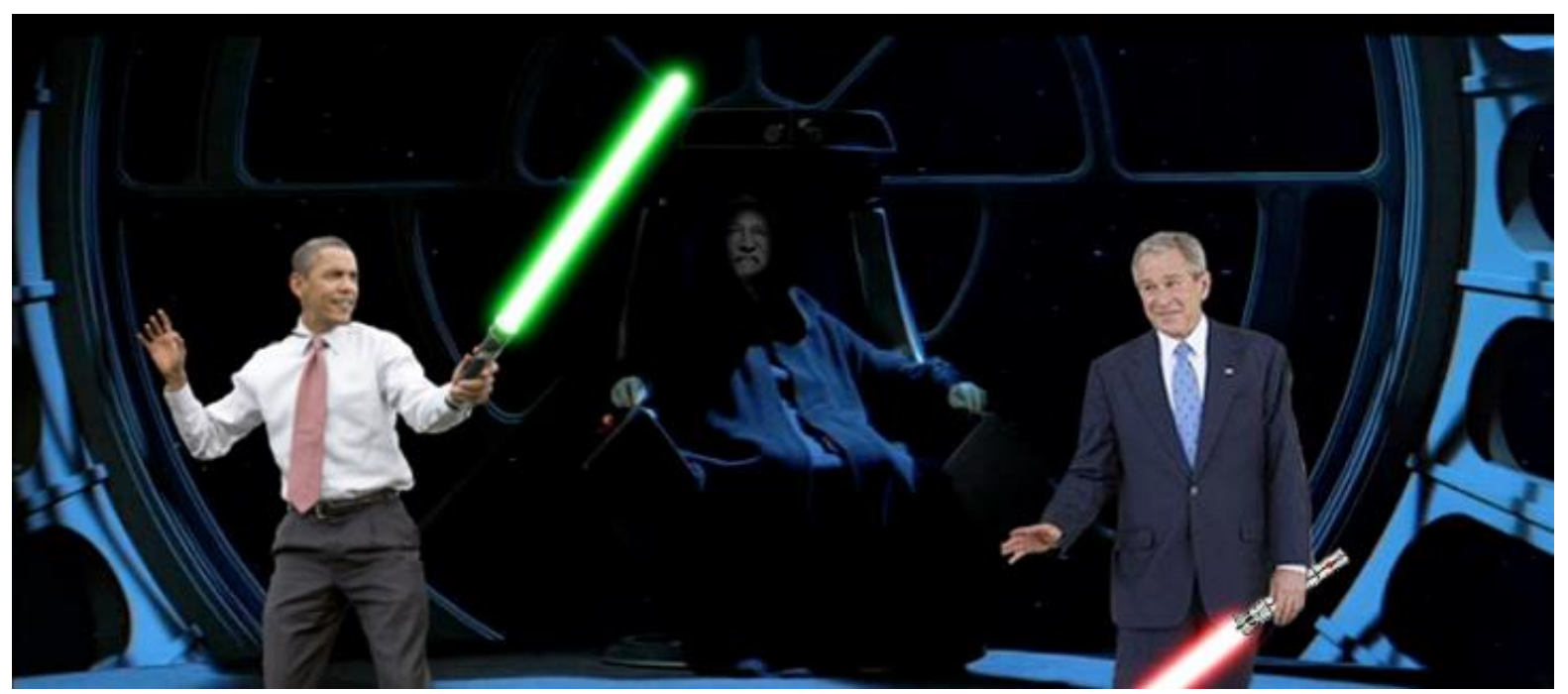

Figure 33. Lightsaber Obama.

It did, however, have political consequences. The meme became a major part of a positive cultural resurgence towards Hillary Clinton as a political figure, which is especially potent as a 2016 Presidential run is already being considered. This already makes her a viable candidate. With just 32 entries, the Tumblr blog's creators decided to "stop while we're ahead", after a week that included over 83,000 Facebook shares, 8,400 followers on their attached Twitter feed, and more than 45,000 Tumblr followers (Texts with Hillary 2012). The creators' retirement did not stop new images from being continuously created and circulated across the web, furthering the reach of the meme. The reception was also clearly favourable offline - part of the reason behind discontinuing the blog was because the creators decided that they were unable to top the ultimate result, meeting Hillary Clinton herself, who also posted a submission of her own (Figure 34). Until this point, the notion of a mainstream political figure directly participating in an Internet meme about them was practically unheard of. For Clinton, this shows a visible development in her public image. As a former Presidential candidate who possesses "an antiquated take on technology", she is now "quick to laugh at herself and take advantage of the positive buzz" (Dowd 2012). Her own playful submission even utilises popular texting jargon. 


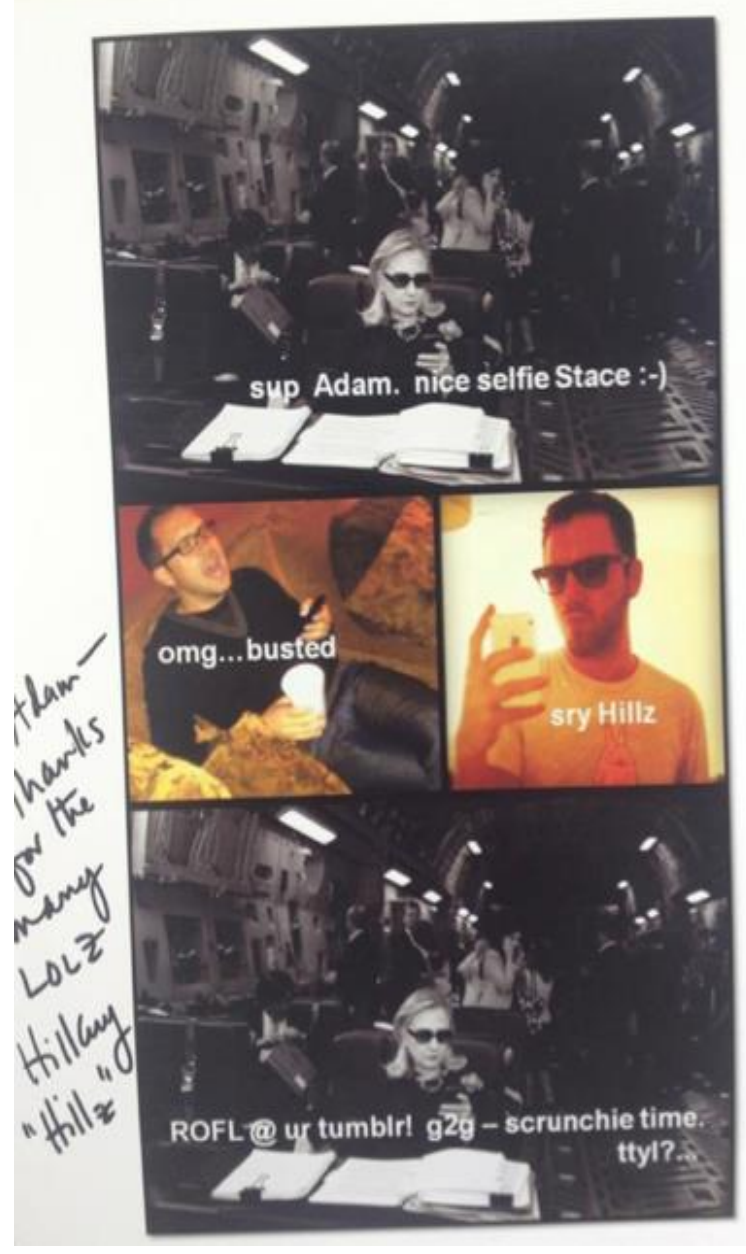

Figure 34. Clinton's own Text with Hillary.

Texts with Hillary's impact on Clinton's political image is inarguable. She gained from the meme what countless other political figures sought by working hard with public relations and campaign managers, often only to backfire - a quintessentially cool image. Sarlin (cited in Terkel 2012) remarks,

When she was running for the Democratic presidential nomination, Hillary Clinton was parodied as drab and calculated, especially compared with young and vigorous Barack Obama and winking and fresh-faced Sarah Palin. Now, she's fuelling Internet jokes based on her own brand of badass cool.

Clinton has certainly used this to her advantage. The original photographs could have been interpreted in other ways. MSNBC"s Suzanne Choney (2012) suggests, "[r]ather than looking hungover or like a vampire, Clinton embodies the third thing someone wearing sunglasses inside might be - cooler than your brain could possibly comprehend". The meme has altered the context of the photograph entirely, and its reinterpretation has taken over the original photograph's dominant discourse. Even without the captions, it became a recognisable piece symbolising Clinton's coolness. It is also very clear that the political figure is fully aware of this. When Hillary Clinton finally joined Twitter on June 10, 2013, she used the original TIME photograph as both her avatar and cover image. Her Twitter profile also reflects her playful and confident new persona by including descriptions such as "hair icon" and "pantsuit aficionado" (Figure 35). On April 1, 2014, a year after he joined Twitter, former President 
Bill Clinton also altered his avatar and tweeted a photomanipulated version of himself in his wife's position, stating, "I'm following my leader!" (Figure 36). Bill Clinton's awareness of the joke and its positive reception is obvious, even two years after the meme's creation. The original photograph of Hillary Clinton was also plastered at the back of her "Ready for Hillary" campaign tour bus sighted in June 2014, and most recently, on the back cover of her official memoir, Hard Choices, amongst a collage of other standard, "serious" press photographs (Ritzen 2014).

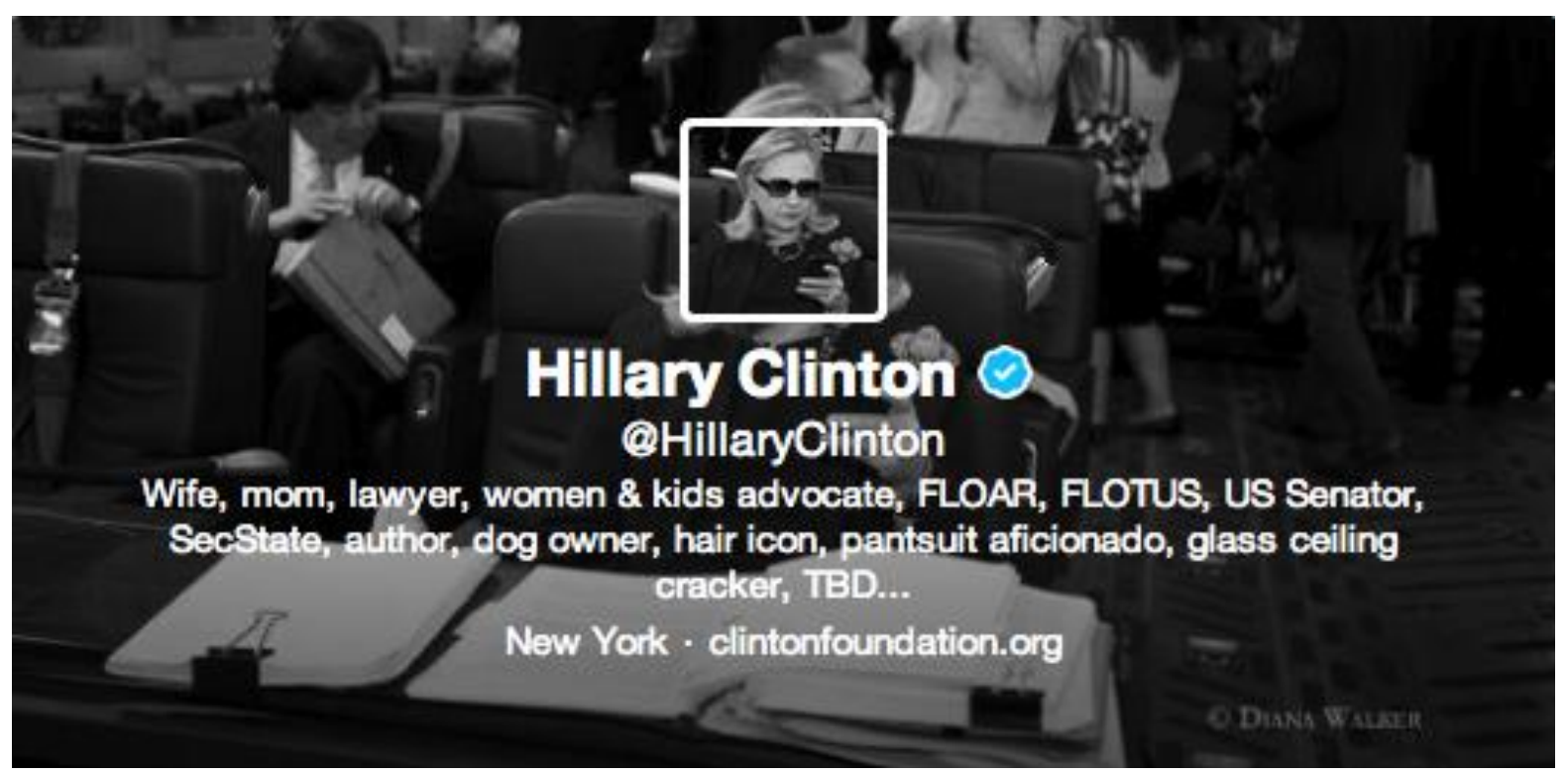

Figure 35. Hillary Clinton's Twitter account in 2013. The images remain unchanged.

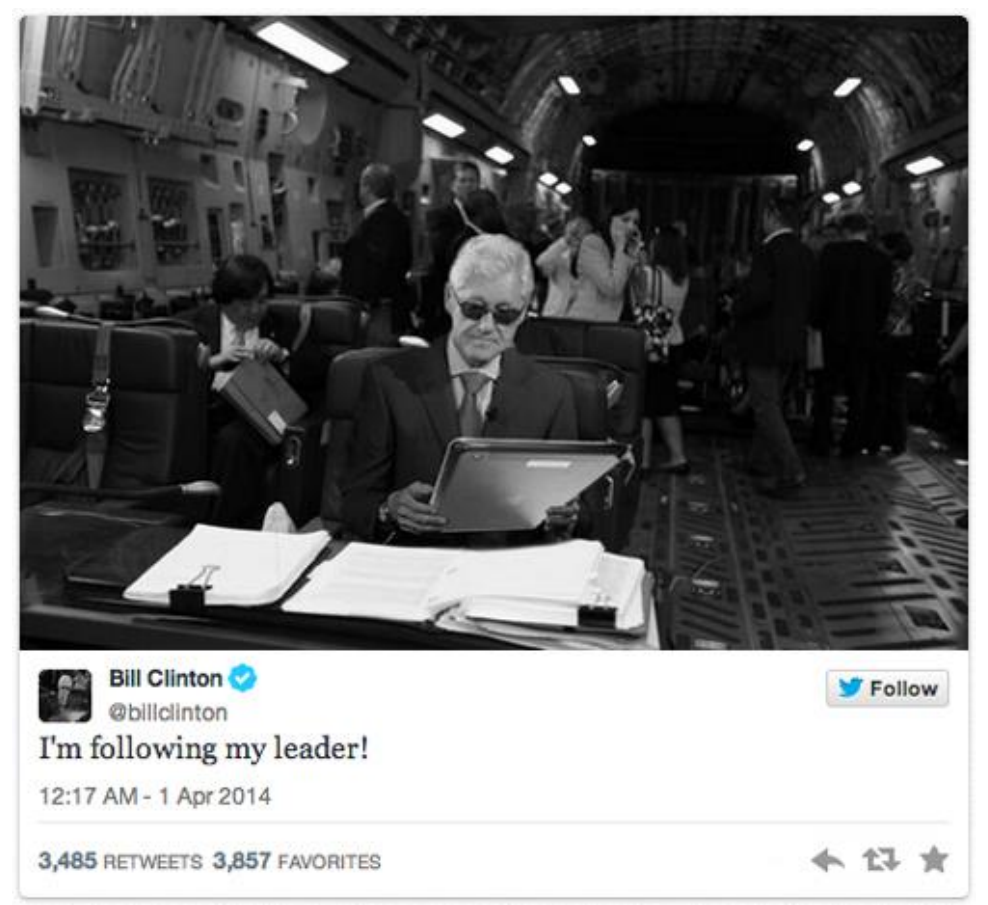

Figure 36. Bill imitates Hillary. 


\section{Discussion}

Hillary Clinton is certainly not the first politician to capitalise on Internet memes or popular forms of political participation. Barack Obama, touted as 2008's "cool" candidate, is known to adopt mainstream tools utilised mostly by young people. His campaign even posted a LOLcat a few days before the 2012 election (Figure 37). More recently, some Republican representatives made unsuccessful attempts at co-opting memes for the benefit of their own political commentary. On December 24, 2013 both Representatives Steve Stockman and Thomas Massie chastised their opponents by using the "Doge" meme (Horowitz 2013). Unlike Texts with Hillary, the Republicans were criticised for "trying too hard". With these incidents in mind, questions should be raised about how politics will be marketed in the near future. The evidence here suggests that it might take both a compelling offline personality and fluency with online discourses to produce a "cool", ideal candidate. When politicians do finally master the art of manipulating popular discourses online, LOLitics, because of their constant ability to replicate to suit different contexts, may well have moved ahead of them.

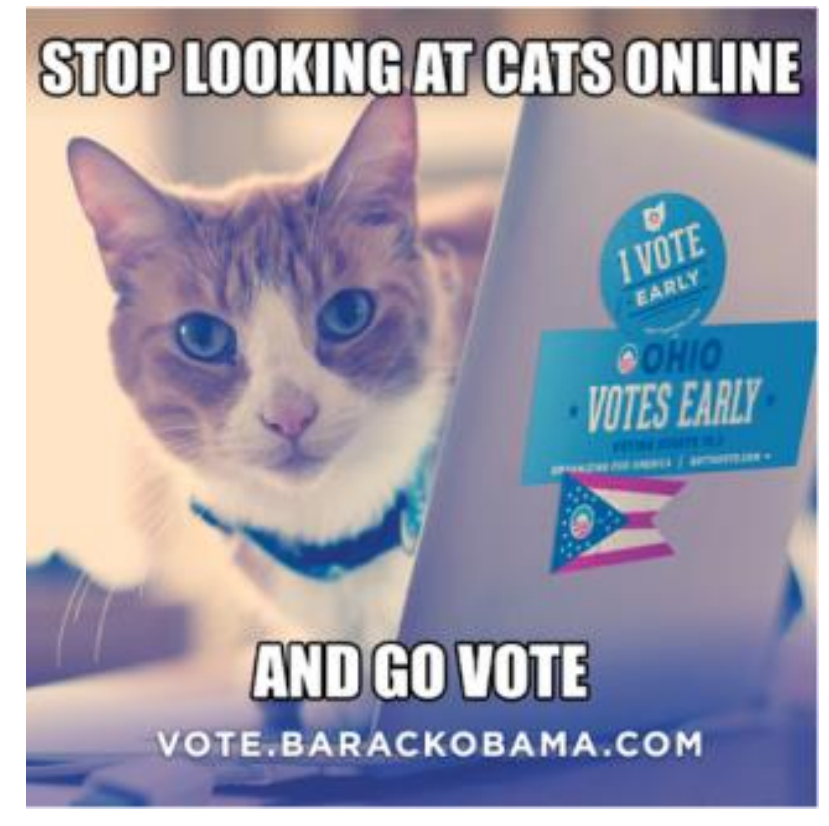

Figure 37. The Obama campaign's LOLcat.

Simply, LOLitics demand more scholarly attention. There are still many aspects of the form open for exploration using different methodological approaches. The space LOLitics provided for citizen commentary has fundamentally increased between the past two US Presidential elections. As the digital landscape and its participants continue to develop, there will be inevitable changes to the shape of the citizen discourse on politics. As a new addition to the election political humour repertoire, 2012's single-topic Tumblr blogs prove to be reflective of the need for immediacy and participation in jokes that target a particular quality, much like the already-regular act of playfully making short jokes on Twitter grouped by "hashtags". The evolution of LOLitics is parallel to that of technology, and how users interact with it. 2008 demonstrated the success of the Obama campaign's grassroots approach and use of digital platforms to bypass traditional media outlets. In 2012, online participation by voters -rather than campaigns themselves- became crucial, while traditional media became less of an authoritative source for information (Pew Research Center 2012). This has pushed news outlets to cover user-generated products, a trend that is now commonplace on many popular 
culture websites, and also traditional media. The mainstream conversation now extends beyond just pure news, politics, and mainstream pop culture to now include Internet humour. LOLitics are now just one of the many forms of engagement available for constant play and exploitation.

Because their popularity still remains largely in the realm of ordinary individuals, LOLitics justifiably contain the potential to be politically mobilising, or at the very least, educational. To participate in the meme-making process is to learn about humour practice that is contained within particular grammatical, stylistic, or community rules (Lankshear \& Knobel 2006: 6). To date, the full capabilities of LOLitics in political mobilisation and education remain to be seen. Internet memes can be transient, and often do not extend beyond their specific periods of significance. Their impact on the mainstream news agenda can nonetheless allow ordinary citizens a chance to make their voices heard, even if their opinions may initially appear frivolous and benign. With enough online traction, a playful piece has the potential to dominate mainstream news coverage. The latter, in turn, are more prone to seeing the benefits of covering citizen discourses. As Hess (2012) explains, "[b]y following and researching and translating memes, they can key into the issues and values relevant to at least some segments of American voters - including those, like women, whose issues are sometimes neglected". Like many good jokes or pop culture pieces, memes can also return much later to contextualise arguments. When President Obama chose only to speak to female reporters in his 2014 end-of-year press conference, one of the most popular tweets was by $C N N$ journalist Brenna Williams (cited in Aleem 2014) who wrote, "Briefings Full of Women > Binders Full of Women".

Today, LOLitics can be as much a part of the overall media ecosystem as they are digital 'inside jokes', and users truly began to harness this benefit during the 2012 Presidential election. Still, in many cases, all that matters is play for play's sake. Producers and consumers of LOLitics tend to be motivated by, and gain more satisfaction out of entertaining each other, rather than engaging in heated political debates. This pleasure, often associated with consuming entertainment and popular culture, is now applicable to politics. Humour functions as an inclusive, dominant form of online communication, not unlike the safety and relief mainstream political satire provides. Additionally, cultural allusions are often playfully incorporated to allow users to produce commentary in a manner that ordinary people can relate to. In regards to a series of photomanipulated images of The White House Situation Room bombarded by popular culture characters after the 2011 assassination of Osama bin Laden, Al Madrigal (2011) writes, "the Situation Room has been colonised. It is part of our world". If the act of incorporating one's culture to make sense of another is a pertinent quality of play and memes, perhaps this is why LOLitics will remain significant to the way we communicate about news and politics.

\section{Notes}

${ }^{1}$ The acronym for Graphics Interchange Format, which is often used to refer to animated still images.

2 Popular examples include "The Story of Egypt's Revolution in Jurassic Park Gifs", and

"The Hills Explains Vladimir Putin Invading Ukraine". 


\section{References}

Aleem, Z. (2014). 'Obama just made history by ignoring men for an entire press conference'. Mic. URL: http://mic.com/articles/106924/obama-made-history-by-ignoring-men-for-anentire-press-conference [Accessed 21 December 2014].

Basler, R. (2011). 'Do we get a snack on this flight, or what?' Reuters. URL: http://blogs.reuters.com/oddly-enough/2011/10/20/do-we-get-a-snack-on-this-flight-orwhat/ [Accessed 3 July 2014].

Bingham, A. (2012). 'The presidential debate's biggest loser: Big Bird'. URL: http://abcnews.go.com/blogs/politics/2012/10/the-presidential-debates-biggest-loser-bigbird/ [Accessed 3 July 2014].

Bobic, I. (2012). 'Women dressed as binders protest at Ohio GOP HQ'. Talking Points Memo. URL: http://talkingpointsmemo.com/livewire/women-dressed-as-binders-protestat-ohio-gop-hq-photos [Accessed 28 June 2014].

Buell, E. H. \& Maus, M. (1988). 'Is the pen mightier than the sword? Editorial cartoons and 1988 presidential nominating politics'. Political Science and Politics 21 (4), pp. 847-858.

Cardona, M. (2012). 'Romney's empty "binders full of women"'. CNN. URL: http://edition.cnn.com/2012/10/17/opinion/cardona-binders-women/index.html [Accessed 28 June 2014].

Casey, M. (2012). 'Creator of "Texts from Hillary" Explains the Anatomy of Buzz'. The Huffington Post. URL: http://www.huffingtonpost.com/mike-casey/creator-of-texts-fromhil_b_1833958.html [Accessed 9 July 2014].

CNN Political Unit (2012). Transcript of Wednesday's presidential debate. CNN. URL: http://edition.cnn.com/2012/10/03/politics/debate-transcript/index.html [Accessed 29 June 2014].

Conners, J. L. (2005). 'Visual representations of the 2004 presidential campaign: Political cartoons and popular culture references'. American Behavioural Scientist 49 (3), pp. 479487.

Danung, J. \& Attaway, L. H. (2008). 'All your media are belong to us: An analysis of the cultural connotations of the internet meme'. URL: http://bth.danung.com/danung_rsch.doc [Accessed 2 May 2014].

Dowd, M. (2012). 'State of cool'. The New York Times, 10 April. URL: http://www.nytimes.com/2012/04/11/opinion/dowd-state-ofcool.html? r=2\&ref=opinion\& [Accessed 15 July 2014].

Edwards, J. L. (2001). 'Running in the shadows in Campaign 2000: Candidate metaphors in editorial cartoons'. American Behavioural Scientist 44 (12), pp. 2140-2151.

Fiske, J. (1987). Television Culture. London: Routledge.

Garber, M. (2012). 'Hillary Clinton texts like a boss'. The Atlantic. URL: http://www.theatlantic.com/technology/archive/2012/04/hillary-clinton-texts-like-aboss/255520/ [Accessed 15 July 2014].

Garfield, B. \& Gladstone, B. (2011). 'What makes a gaffe so sticky?'. On the Media, August 19.

Glasser, T. (2000). 'Play and the power of news'. Journalism 1 (1), pp. 23-39.

Griffin, D. (1994). Satire: A Critical Reintroduction. Lexington: The University Press of Kentucky.

Grossman, S. (2012). 'Amazon's binder pages flooded with snarky Romney-related reviews'. TIME. URL: http://newsfeed.time.com/2012/10/18/amazons-binder-pages-flooded-withsnarky-romney-related-reviews/ [Accessed 29 June 2014]. 
Halliday, J. (2013). '11 things you need to know about Buzzfeed'. The Guardian, 6 January. URL: $\quad$ http://www.theguardian.com/media/2013/jan/06/buzzfeed-social-news-open-uk [Accessed 28 May 2014].

Heflin, K. (2006). 'Laughter helps interpret the news'. Television Quarterly 36 (3/4), pp. 2631.

Hess, A. (2012). 'Binders full of Big Bird: The risk and benefits of reporting on memes'. Poynter, 23 October. URL: $\quad$ http://www.poynter.org/latest-news/topstories/192645/binders-full-of-big-bird-the-risk-to-journalism-when-memes-replacemeaning-in-political-journalism/ [Accessed 20 July 2014].

Horowitz, A. (2013). 'GOPers Ruin Beloved Internet Meme'. The Huffington Post, 23 December. URL: http://www.huffingtonpost.com/2013/12/23/gop-meme_n_4493685.html [Accessed 16 July 2014].

Huizinga, J. (1949). Homo Ludens: A Study of the Play-Element in Culture. London: Routledge.

Jeffries, A. (2012). 'In 2012 election, the meme factory hones its assembly line'. The Verge. URL: http://www.theverge.com/2012/10/24/3541836/2012-presidential-election-memes [Accessed July 9 2014].

Jenkins, H. (2009). 'If It doesn't spread, it's dead (part one): Media viruses and memes'. Confessions An Aca-Fan. URL: http://www.henryjenkins.org/2009/02/if_it_doesnt_spread_its_dead_p.html [Accessed 22 June 2014].

Jenkins, H. (2011). 'Shall we play? (part one)'. Confessions Of An Aca-Fan. URL: http://henryjenkins.org/ 2011/05/shall_we_play.html [Accessed 27 June 2014].

Jones, J. P. (2010). Entertaining Politics: Satiric Television and Political Engagement. Second Edition. Lanham: Rowman \& Littlefield.

Karp, D. (2012) 'Tumblr insights: Election 2012 report'. Tumblr Staff Blog. URL: http://staff.tumblr.com/post/16780220714/ tumblr-insights-election-2012-report-with-the [Accessed 15 June 2014].

Lankshear, C. \& Knobel, M. (2008). 'Introduction', in Lankshear, C. \& Knobel, M. (eds), Digital Literacies: Concepts, Policies and Practices, New York: Peter Lang, pp. 1-16.

Lloyd, M. \& Jewell, P. (2009). 'Where Did That Fokker Come From? 'The Age's Adventures of Naked Man' Cartoon Caption Competition'. Media International Australia 133, pp. 56-67.

Madrigal, A. (2011). 'The Situation Room meme: The shortest route from bin Laden to LULZ'. The Atlantic. URL: http://www.theatlantic.com/technology/archive/2011/05/thesituation-room-meme-the-shortest-route-from- bin-laden-to-lulz/238251/ [Accessed 22 July 2014].

Medhurst, M. J. \& DeSousa, M. A. (1981). 'Political cartoons as rhetorical form: A taxonomy of graphic discourse'. Communication Monographs 48 (3), pp. 197-236.

Melber, A. (2012). 'Why Romney Is Losing the Meme Election'. The Nation, October 17. URL: http://www.thenation.com/blog/170648/why-romney-losing-meme-election\%23\# [Accessed 28 June 2014].

Mezrahi, S. (2012). 'Relatable Romney: A Meme For Rich People To Relate To'. Buzzfeed, 21 July. URL: http://www.buzzfeed.com/samir/relatable-romney-a-meme-for-rich-peopleto-relate [Accessed 8 June 2014].

Newsweek (2012). 'Tumblr Wednesday: 5 questions with Unpopular Opinion Rick Perry'. URL: http://newsweek.tumblr.com/post/14224846450/tumblr-wednesday-5-questionswith-unpopular-opinion [Accessed 28 May 2014]. 
O’Neal, S. (2012). 'The Lucille Bluth/Mitt Romney Tumblr confirms that saying awful rich person things is all about context'. The AV Club. URL: http://www.avclub.com/article/thelucille-bluthmitt-romney-tumblr-confirms-that--85333 [Accessed 6 June 2014].

Obama for America (2012). 'Big Bird - Obama for America TV ad'. YouTube. URL: http://www.youtube.com/watch? $\mathrm{v}=\mathrm{bZxs} 09 \mathrm{eV}-\mathrm{Vc}$ [Accessed 8 July 2014].

Parker, S. (2012). 'Big Bird will haunt Mitt Romney'. The Washington Post, 4 October. URL: http://www.washingtonpost.com/blogs/she-the-people/wp/2012/10/04/big-bird-willhaunt-mitt-romney/ [Accessed 20 July 2014].

Poster, M. (2006). Information Please: Culture and Politics in the Age of Digital Machines. London: Duke University Press.

Pew Research Center (2012). 'How the Presidential Candidates Use the Web and Social Media'. Pew Research Journalism Project, 15 August. URL: http://www.journalism.org/2012/08/15/how-presidential-candidates-use-web-and-socialmedia/ [Accessed 25 July 2014].

Relatable Romney (2012a). URL: http://relatableromney.com/ [Accessed 3 June 2014].

Relatable Romney (2012b). URL: https://twitter.com/RelatableRomney [Accessed 3 June 2014].

Rick Perry's Unpopular Opinions (2012). 'And that's all folks!' URL: http://rickperryheadlines.tumblr.com/post/16836234910/and-thats-all-folks [Accessed 10 June 2014].

Ritzen, S. (2014). 'The back of Hillary Clinton's tour bus has amazingly self-aware messaging'. Uproxx. URL: http://uproxx.com/up/2014/06/the-back-of-hillary-clintonstour-bus-has-amazingly-self-aware-psa-messaging/ [Accessed 18 July 2014].

Romnoid (2012). 'Romnoid: The Republican Android'. URL: http://romnoid.tumblr.com/ [Accessed 28 June 2014].

RPerry2012 (2011). 'Strong'. YouTube. URL: http://youtu.be/OPAJNntoRgA [Accessed 8 December 2011].

Rutkoff, A. (2007). 'With "LOLcats" internet fad, anyone can get in on the joke'. The Wall Street Journal, 25 August. http://online.wsj.com/article/SB118798557326508182.html [Accessed 14 June 2014].

Street, J. (2003). 'The celebrity politician: Political style and popular culture', in Corner, J. \& Pels, D. (eds.), Media and the Restyling of Politics: Consumerism, Celebrity and Cynicism, London: Sage, pp. 85-89.

Sun, F. \& Moakley, P. (2012). 'That photograph that has everyone texting Hillary Clinton'. TIME, 9 April. URL: http://lightbox.time.com/2012/04/09/texting-hillary-clinton/\#1 [Accessed 3 July 2014].

Terkel, A. (2012). 'Hillary Clinton thanks "Texts from Hillary" guys for the "LOLZ". The Huffington Post, 4 October. URL: http://www.huffingtonpost.com/2012/04/10/texts-fromhillary-clinton_n_1415551.html [Accessed 14 July 2014].

Texts with Hillary (2012). Tumblr, 11 April 2012. URL: http://textsfromhillary.tumblr.com/post/20912989658/its-been-an-overwhelming-andhilarious-week-for\#notes [Accessed 14 July 2014].

Wired (2012). 'Herding LOLcats'. May 2011, p. 28. 